\title{
Reclamation of Cobalt and Copper from Single- and Co-contaminated Wastewater via Carbonate and Hydroxide Precipitation
}

\section{Khyle Glainmer Quiton}

National Cheng Kung University

Ming-Chun Lu

National Chung Hsing University

Yao-Hui Huang ( $\nabla$ yhhuang@mail.ncku.edu.tw )

National Cheng Kung University

\section{Research}

Keywords: chemical precipitation, cobalt removal, copper system, hydroxide precipitation, wastewater stream

Posted Date: October 18th, 2021

DOl: https://doi.org/10.21203/rs.3.rs-910544/v1

License: (c) (1) This work is licensed under a Creative Commons Attribution 4.0 International License. Read Full License 
22

$23 *$ Correspondence: yhhuang@ mail.ncku.edu.tw

$24 * *$ Correspondence: mmclu@ nchu.edu.tw

11

2

10

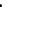

4

15

6

17

8

9

0

21

\section{carbonate and hydroxide precipitation}
Taiwan
Khyle Glainmer N. Quiton ${ }^{1}$, Ming-Chun Lu ${ }^{2 * *}$, Yao-Hui Huang ${ }^{1 *}$
${ }^{1}$ Department of Chemical Engineering, Sustainable Environment Research Center, National

\section{Reclamation of cobalt and copper from single- and co-contaminated wastewater via}




\section{Abstract}

26 Wastewater containing cobalt and copper comprised of plating wash water, plant wash water, and

27 equipment cooling and wash water is generated in the electroplating industry. These metals can be

28 detrimental to humans, animals, plants, and the environment. Thus, it is necessary to treat

29 electroplating wastewater to remove these toxic metals. Carbonate and hydroxide precipitation

30 were utilized for the removal of $\mathrm{Co}$ (II) and $\mathrm{Cu}$ (II) from synthetic electroplating wastewater by jar

31 tests in this work. The effects of solution $\mathrm{pH}$, precipitant-to-metal ratio, and type of precipitant on

32 the precipitation efficiency of cobalt and copper from the single- and co-contaminated systems

33 were investigated. Carbonate precipitation achieved higher removal efficiency for both target

34 metals in the single- and co-contaminated wastewater streams. Furthermore, it can operate at

35 relatively low $\mathrm{pH}$ range of about 7.0-8.0. Cobalt in both pollutant systems was almost completely removed at $\mathrm{pH} 10.0$ using both precipitant systems. Copper was found to be easily removed which

37 was possibly brought about by precipitation-adsorption mechanism. The extent of the co-removal

of cobalt with copper is significantly $\mathrm{pH}$ dependent. The effect of precipitant-to-metal ratio for cobalt and copper treatment varied in single- and co-contaminated streams. Carbonate precipitation led to lower sludge density than that of hydroxide precipitation.

Keywords: chemical precipitation; cobalt removal; copper system; hydroxide precipitation; wastewater stream 


\section{Introduction}

51 With the progressing economy, and rapid growth and development of industries including mining

52 and smelting operations, leather tanning, metal plating facilities, metal cleaning and fabrication,

53 metal finishing, battery manufacturing, electrochemical, paint and pigment industries, heavy

54 metals are being discharged into the aquatic streams to an increasing degree [1]. These recalcitrant

55 and persistent pollutants are considered toxic, carcinogenic, and non-biodegradable which pose

56 detrimental effects on biological environment and human health [2]. Thus, remediation of these

57 contaminants in water and wastewater have been of particular concern.

58 Cobalt is a significant cofactor in Vitamin B12 responsible for the proper functioning of the

59 brain and nervous system, and for blood formation. It is one of the most essential transition metals

60 beneficial to human beings. However, excessive intake may be hazardous to both humans and

61 animals. Moreover, exposure to high levels of cobalt may induce toxic effects and may cause goiter,

62 thyroid damage, diarrhea, nausea, reproductive problems, hypertension, heart disease, bleeding,

63 pulmonary diseases, hyperglycemia, hair loss, bone defects, and mutations in living cells [3,4].

64 With this, cobalt concentration in livestock wastewater and irrigation water should not exceed 1.0

65 and $0.05 \mathrm{mg} \mathrm{L}^{-1}$, respectively [4]. On the other hand, copper is another beneficial metal ion present

66 as trace amounts in our body and water resources. It regulates hemoglobin level, neuron action,

67 mitochondrial respiration, and metabolism by cells. At higher concentrations, liver and kidneys

68 can be affected to a great extent. Its accumulation can cause diseases such as anemia, Alzheimer's

69 disease, and Parkinson's disease [5-8]. The permissible limits of copper in drinking water and

70 effluent discharge are set to 2.0 and $1.3 \mathrm{mg} \mathrm{L}^{-1}$, respectively [6]. At present, chemical precipitation,

71 coagulation/flocculation, electrochemical method, ion exchange, membrane filtration and

72 adsorption are the existing treatment technologies to remove heavy metals in water and wastewater 
73 streams $[9,10]$. Among these current methods, chemical precipitation is the most widely utilized

74 method in the industry particularly due to the simplicity of process control, effectivity over a wide

75 range of temperature and relatively low operating cost $[9,11]$. Traditionally, chemical precipitation

76 processes produce insoluble precipitates of heavy metals in the form of hydroxides, sulfides,

77 carbonates, and phosphates. Chemical precipitation mechanism involves the reaction of dissolved

78 metals in the solution with the precipitating agent producing insoluble metal precipitates.

79 Consequently, very fine particles are generated, and their particle size can increase by using

80 chemical precipitants, coagulants, and flocculation leading to removal as sludge. Once the metals

81 precipitate leading to the formation of solids, they can easily be removed, and low metal

82 concentrations can consequently be released. Removal efficiency of metal ions in the solution can

83 reach optimum by changing the significant parameters including $\mathrm{pH}$, temperature, initial metal

84 concentration and charge of the ions [12]. Chemical precipitation process usually involves addition

85 of reagents, $\mathrm{pH}$ adjustment inducing precipitation, flocculation, sedimentation and solid-liquid

86 separation [11]. Oftentimes, alkaline reagents are utilized to raise the $\mathrm{pH}$ of the solution lowering

87 the solubility of the metallic constituent, consequently leading to precipitation. It includes sulfide,

88 hydroxide and carbonate precipitation [13]. Operating costs for hydroxide and carbonate

89 precipitation processes are almost similar. They are of lower cost than sulfide precipitation [14].

90 Hydroxide precipitation removes heavy metals by the addition of alkalis (caustic or lime) to

91 adjust the $\mathrm{pH}$ of the wastewater until the pollutant metal exhibits its minimum solubility. It is easy

92 to operate, operates at ambient conditions, and appropriate for automatic control. The most

93 significant advantage of this process is its low cost [15]. On the other hand, carbonate precipitation

94 using sodium carbonate $\left(\mathrm{Na}_{2} \mathrm{CO}_{3}\right)$ is a low-cost chemical precipitation process with added 
95 advantages such as its simplicity, optimum treatment occurring at less $\mathrm{pH}$ levels and sludges with 96 good filtration characteristics [11].

97 Few investigations have utilized chemical precipitation method in treating co-contaminated 98 heavy metal wastewater streams, particularly containing cobalt and copper. Thus, the aim of the 99 study is to investigate the influence of $\mathrm{pH}$, precipitant-to-metal ratio, and type of precipitant on the 100 co-removal of cobalt with copper from synthetic electroplating wastewater using carbonate and 101 hydroxide precipitating agents since these pollutants co-exist in the said wastewater stream. 102 Single-contaminated synthetic wastewater was also treated for comparison in terms of removal 103 efficiency, and sludge volume generation.

\section{2. Materials and methods}

\section{2.1. Chemicals}

107 All reagents were of analytical grade and used without further purification. Cobalt sulfate 108 heptahydrate (99\%) was purchased from Sigma-Aldrich (China). Copper sulfate pentahydrate $109(\geq 98.5 \%)$ and sodium carbonate $(\geq 99.5 \%)$ were provided by Fluka (Switzerland). Sodium 110 hydroxide $(\mathrm{NaOH}, \geq 97 \%)$ was obtained from Fisher Chemical (UK). Nitric acid $\left(\mathrm{HNO}_{3}\right)$ was 111 purchased from Shimakyu's Pure Chemicals (Japan). A laboratory-grade RO-ultrapure water 112 system (resistance $>18.1 \Omega$ ) supplied deionized water for the experiments.

\section{2.2. Batch experiments}

115 Single-contaminated aqueous solutions of cobalt and copper with $12.6 \mathrm{mM}$ concentration were 116 prepared as well as co-contaminated aqueous stream where initial concentration of each metal was

$11712.6 \mathrm{mM}$ where the molar ratio of $\mathrm{Co}$ to $\mathrm{Cu}$ is $1: 1$. Batch experiments of chemical precipitation 
118 were conducted by jar tests as shown in Fig. 1 at different $\mathrm{pH}$ levels of 7.0, 8.0, 9.0, 10.0, 11.0,

119 and 12.0, and precipitant-to-metal ratios $([\mathrm{P}] /[\mathrm{M}])$ of $0.5,1.0,1.5,2.0$, and 2.5. All the

120 experimental runs were carried out at room temperature. $\mathrm{Na}_{2} \mathrm{CO}_{3}$ and $\mathrm{NaOH}$ were used for

121 carbonate and hydroxide precipitant precursors, respectively, to determine the effect of precipitants

122 on the treatment of single- and co-contaminated streams. The mixture was stirred at $100 \mathrm{rpm}$ for

$12310 \mathrm{~min}$ then $30 \mathrm{rpm}$ for $50 \mathrm{~min}$, and finally kept for settling to draw liquid sample for residual 124 cobalt and copper analysis. For the cobalt and copper residue, the supernatant liquid was filtered 125 with $0.22 \mu \mathrm{m}$ syringe filter and digested with $1 \mathrm{~mL} \mathrm{HNO}_{3}(70 \%)$ to stop precipitation.

126

\section{$127 \quad 2.3$. Analytical methods}

128 Volumetric method was used to determine the estimated volume of the decanted sludge. The 129 sludge volume at $30 \mathrm{~min}\left(\mathrm{SV}_{30}\right)$ was determined using an Imhoff cone (Kartell Labware, Italy). 130 The sludge settling rate $\left(\mathrm{SSR}, \mathrm{cm}^{3} \mathrm{~min}^{-1}\right)$ was determined in the reaction system given by Eq. (1). 131 Cobalt and copper residues were measured by using inductively coupled plasma mass 132 spectrometry (ICP-OES, JY 2000-2, HORIDA).

$$
\text { Sludge settling rate, } \operatorname{SSR}\left(\frac{\mathrm{cm}^{3}}{\min }\right)=\frac{\mathrm{V}_{\mathrm{sol} / \mathrm{n}}-\mathrm{SV}_{30}}{\mathrm{t}_{\mathrm{s}}}
$$

134 Where $\mathrm{V}_{\text {sol'n }}$ is total volume of the solution $\left(\mathrm{cm}^{3}\right), \mathrm{SV}_{30}$ is the sludge volume at $30 \mathrm{~min}\left(\mathrm{~cm}^{3}\right)$ and $135 \mathrm{t}_{\mathrm{s}}$ is the settling time $(30 \mathrm{~min})$.

\section{Results and discussion}

\subsection{Theoretical computations}

139 The treatability of $\mathrm{Co}$ and $\mathrm{Cu}$ via chemical precipitation in waste abatement applications is directly 140 related to their solubilities in the solvent matrix. Their solubility profiles can be altered by one or 
141 more of the following process modifications: (1) controlling the temperature of an aqueous

142 solution, (2) adjusting the $\mathrm{pH}$ and reduction potential of the solution, or (3) setting supersaturation

143 in a fixed-volume solution $[16,17]$.

144

145 3.1.1. Cobalt speciation

146 Fig. 2a displays the distribution of soluble species of individual hydroxo $\mathrm{Co}^{2+}$ complexes. These 147 hydro complexes always exist in water while different anions can form complexes with cobaltous 148 ion based on stability constants. Common anions include $\mathrm{SO}_{4}{ }^{2-}, \mathrm{OH}^{-}, \mathrm{PO}_{4}{ }^{3-}, \mathrm{HCO}_{3}{ }^{-}, \mathrm{NO}_{3}{ }^{-}$and $149 \mathrm{CO}_{3}{ }^{2-}$. These complexes form precipitates when the solubility product is surpassed [18]. Cobaltous 150 ions, $\mathrm{Co}^{2+}$, exist in acid and weak alkaline solutions depending on the extent of cobalt 151 concentration. Increasing the $\mathrm{pH}$ will allow $\mathrm{Co}^{2+}$ to react with $\mathrm{OH}^{-}$ions forming cobaltous 152 hydroxide, $\mathrm{Co}(\mathrm{OH})_{2}$. Nevertheless, the $\mathrm{Co}(\mathrm{OH})_{2}$ precipitate may undergo re-dissolution into 153 dicobaltite ions, $\mathrm{HCoO}_{2}^{-}$, when the $\mathrm{pH}$ reaches greater than 13.4. Hydrolysis products of $\mathrm{Co}^{2+}$ are 154 summarized varying from $\mathrm{CoOH}^{+}$to $\mathrm{Co}(\mathrm{OH})_{4}{ }^{2-}[19]$ as indicated in Eqs. (2) to (5) together with 155 their respective solubility products.

156

$\mathrm{Co}^{2+}+\mathrm{H}_{2} \mathrm{O} \rightleftharpoons \mathrm{CoOH}^{+}+\mathrm{H}^{+} \quad\left(\beta_{1}=\frac{\left[\mathrm{CoOH}^{+}\right]\left[\mathrm{H}^{+}\right]}{\left[\mathrm{Co}^{2+}\right]}=10^{-9.6}\right)$

157

$\mathrm{Co}^{2+}+2 \mathrm{H}_{2} \mathrm{O} \rightleftharpoons \mathrm{Co}(\mathrm{OH})_{2}{ }^{0}+\mathrm{H}^{+} \quad\left(\beta_{2}=\frac{\left[\mathrm{Co}(\mathrm{OH})_{2}{ }^{0}\right]\left[\mathrm{H}^{+}\right]^{2}}{\left[\mathrm{Co}^{2+}\right]}=10^{-18.8}\right)$

158

$\mathrm{Co}^{2+}+3 \mathrm{H}_{2} \mathrm{O} \rightleftharpoons \mathrm{Co}(\mathrm{OH})_{3}{ }^{-}+3 \mathrm{H}^{+} \quad\left(\beta_{3}=\frac{\left[\mathrm{Co}(\mathrm{OH})_{3}{ }^{-}\right]\left[\mathrm{H}^{+}\right]^{3}}{\left[\mathrm{Co}^{2+}\right]}=10^{-31.5}\right)$

$\mathrm{Co}^{2+}+4 \mathrm{H}_{2} \mathrm{O} \rightleftharpoons \mathrm{Co}(\mathrm{OH})_{4}{ }^{2-}+4 \mathrm{H}^{+} \quad\left(\beta_{4}=\frac{\left[\mathrm{Co}(\mathrm{OH})_{4}{ }^{2-}\right]\left[\mathrm{H}^{+}\right]^{4}}{\left[\mathrm{Co}^{2+}\right]}=10^{-46.3}\right)$ 
163 The total cobalt in water can be presented as

$164[\mathrm{Co}]_{\mathrm{T}}=\left[\mathrm{Co}^{2+}\right]+\left[\mathrm{CoOH}^{+}\right]+\left[\mathrm{Co}(\mathrm{OH})_{2}{ }^{o}\right]+\left[\mathrm{Co}(\mathrm{OH})_{3}{ }^{-}\right]+\left[\mathrm{Co}(\mathrm{OH})_{4}{ }^{2-}\right]$

165 Factoring out $\left[\mathrm{Co}^{2+}\right]$ and substituting Eqs. (2) to (5), Eq. (6) will be depicted as Eq. (7) and then 166 simplified into Eq. (8). Eq. (8) is consequently rearranged as Eq. (9) to determine the value of $167\left[\mathrm{Co}^{2+}\right]$.

$168[\mathrm{Co}]_{\mathrm{T}}=\left[\mathrm{Co}^{2+}\right]\left(1+\frac{\beta_{1}}{\left[\mathrm{H}^{+}\right]}+\frac{\beta_{2}}{\left[\mathrm{H}^{+}\right]^{2}}+\frac{\beta_{3}}{\left[\mathrm{H}^{+}\right]^{3}}+\frac{\beta_{4}}{\left[\mathrm{H}^{+}\right]^{4}}\right)$

$169[\mathrm{Co}]_{\mathrm{T}}=\left[\mathrm{Co}^{2+}\right] \cdot \alpha_{\mathrm{Co}}$

$170 \quad\left[\mathrm{Co}^{2+}\right]=\frac{[\mathrm{Co}]_{\mathrm{T}}}{\alpha_{\mathrm{Co}}}$

171 Carbonate and hydroxyl anions react with cobalt cation to form $\mathrm{CoCO}_{3}, \mathrm{Co}(\mathrm{OH})_{2}$, or cobalt 172 hydroxide carbonate as shown in Eqs. (10) and (11) [20]. In this case, cobalt hydroxide shows 173 lesser solubility indicated in its smaller solubility product constant which pertains to higher 174 probability of precipitation in the system compared to that of cobalt carbonate.

17

$\mathrm{Co}^{2+}+\mathrm{CO}_{3}^{2-} \rightleftharpoons \mathrm{CoCO}_{3(\mathrm{~s})} \quad\left(\mathrm{K}_{\mathrm{sp}_{1}}=1.4 \times 10^{-13}\right)$

$176 \mathrm{Co}^{2+}+2 \mathrm{OH}^{-} \rightleftharpoons \mathrm{Co}(\mathrm{OH})_{2(\mathrm{~s})}$

$\left(\mathrm{K}_{\mathrm{sp}_{2}}=6.31 \times 10^{-15}\right)$

177 Applying the viewpoint of $\mathrm{K}_{\mathrm{sp}}$ and the equilibrium of water ionization, we can calculate the 178 necessary concentration of precipitant anions required for the formation of $\mathrm{Co}(\mathrm{OH})_{2}$ and $\mathrm{CoCO}_{3}$ 179 precipitates presented in Eqs. (12) and (13), respectively:

$180\left[\mathrm{OH}^{-}\right]=\sqrt{\frac{\mathrm{K}_{\mathrm{sp}\left(\mathrm{Co}(\mathrm{OH})_{2}\right)}}{\left[\mathrm{Co}^{2+}\right]}}$

$181\left[\mathrm{CO}_{3}{ }^{2-}\right]=\frac{\mathrm{K}_{\mathrm{sp}\left(\mathrm{CoCo}_{3}\right)}}{\left[\mathrm{Co}^{2+}\right]}$ 
We apply $12.6 \times 10^{-3} \mathrm{M}$ as the concentration of $\mathrm{Co}^{2+}$ used in this study to determine the precipitant anion concentration. Thus, $7.08 \times 10^{-7} \mathrm{M}$ of $\mathrm{OH}^{-}$is needed to obtain $\mathrm{Co}(\mathrm{OH})_{2}$ precipitate. Whereas $1.11 \times 10^{-11} \mathrm{M}$ of $\mathrm{CO}_{3}{ }^{2-}$ is sufficed to produce $\mathrm{CoCO}_{3}$ in the system.

\subsubsection{Copper speciation}

Like cobalt and other metals, copper interacting with water, forms free metal cations, different soluble complexes and insoluble particles or precipitates. Free copper, which is cupric ion $\left(\mathrm{Cu}^{2+}\right)$, is generally soluble and the preferential form at relatively low degree of $\mathrm{pH}$ (usually below $\mathrm{pH} 6$ ) as shown in Fig. $2 \mathrm{~b}$ and in the absence of anionic ligands [18]. As presented, $\mathrm{Cu}^{2+}$ is the most dominant species (greater than $80 \%$ ) when the $\mathrm{pH}$ is 6.0 but its relative dominance decreased quickly as pH increased [18]. Soluble copper hydro complexes are formed at low and high pH range in pure water and given by the reactions below depicted as Eqs. (14) to (17). In the presence of anionic ligands, these complexes form precipitates such as $\mathrm{Cu}(\mathrm{OH})_{2}, \mathrm{CuCO}_{3}$, etc.

$$
\mathrm{Cu}^{2+}+\mathrm{H}_{2} \mathrm{O} \rightleftharpoons \mathrm{CuOH}^{+}+\mathrm{H}^{+} \quad\left(\beta_{5}=\frac{\left[\mathrm{CuOH}^{+}\right]\left[\mathrm{H}^{+}\right]}{\left[\mathrm{Cou}^{2+}\right]}=10^{-7.497}\right)
$$

$\mathrm{Cu}^{2+}+4 \mathrm{H}_{2} \mathrm{O} \rightleftharpoons \mathrm{Cu}(\mathrm{OH})_{4}{ }^{2-}+4 \mathrm{H}^{+} \quad\left(\beta_{8}=\frac{\left[\mathrm{Cu}(\mathrm{OH})_{4}{ }^{2-}\right]\left[\mathrm{H}^{+}\right]^{4}}{\left[\mathrm{Cu}^{2+}\right]}=10^{-39.6}\right)$

In pure water, the total copper can be depicted as follows:

$$
[\mathrm{Cu}]_{\mathrm{T}}=\left[\mathrm{Cu}^{2+}\right]+\left[\mathrm{CuOH}^{+}\right]+\left[\mathrm{Cu}(\mathrm{OH})_{2}{ }^{\mathrm{o}}\right]+\left[\mathrm{Cu}(\mathrm{OH})_{3}{ }^{-}\right]+\left[\mathrm{Cu}(\mathrm{OH})_{4}{ }^{2-}\right]
$$

$$
\text { Substituting Eqs. (14) to (17), the total copper is presented as }
$$


$203 \quad[\mathrm{Cu}]_{\mathrm{T}}=\left[\mathrm{Cu}^{2+}\right]\left(1+\frac{\beta_{5}}{\left[\mathrm{H}^{+}\right]}+\frac{\beta_{6}}{\left[\mathrm{H}^{+}\right]^{2}}+\frac{\beta_{7}}{\left[\mathrm{H}^{+}\right]^{3}}+\frac{\beta_{8}}{\left[\mathrm{H}^{+}\right]^{4}}\right)$

$204[\mathrm{Cu}]_{\mathrm{T}}=\left[\mathrm{Cu}^{2+}\right] \cdot \alpha_{\mathrm{Cu}}$

205 Thus, the value of $\left[\mathrm{Cu}^{2+}\right]$ is

$206\left[\mathrm{Cu}^{2+}\right]=\frac{[\mathrm{Cu}]_{\mathrm{T}}}{\alpha_{\mathrm{Cu}}}$

208 3.2. Effect of $\mathbf{p H}$

209 The effect of $\mathrm{pH}$ on the removal of cobalt and copper in the single- and co-contaminated systems 210 was studied from $\mathrm{pH}$ levels of 7.0-12.0 treating $12.6 \mathrm{mM}$ initial metal concentration and 211 precipitant-to-metal ratio of 1.2 in $1 \mathrm{~h}$ of reaction time in a batch system. $\mathrm{pH}$ indicates the 212 concentration of hydrogen ions $\left(\mathrm{H}^{+}\right)$in the solution and controls the molecular net electric charge 213 to alter the mobility of a known substance in the water matrix. A heavy metal with relatively low 214 mobility, being insoluble, has a negative net charge $\left(\mathrm{H}^{+}\right.$depletion) leading to precipitation out of 215 the liquid phase. Generally, this phenomenon takes place in high pH zones and is usually termed 216 as alkaline precipitation. Contrarily, a metal exhibiting high mobility (soluble) has a net positive 217 charge caused by $\mathrm{H}^{+}$supplementation in the solution, consequently resulting to aqueous 218 dissolution of metals in acidic environments [21]. Furthermore, the $\mathrm{pH}$ value of the reaction 219 directly influences the concentration of carbonate ions in the reaction system, and then influences 220 nucleation and growth of the crystalline precipitation during the treatment process [20]. Thus, $\mathrm{pH}$ 221 is a relatively significant variable with regards to this process under investigation. The influence 222 of $\mathrm{pH}$ on the behavior of cobalt in the single synthetic solution is presented in Fig. 3a. At stronger 223 alkaline conditions $(\mathrm{pH}>8.0)$, it was found that the cobalt removal efficiency approached 224 complete removal. At $\mathrm{pH}$ 7.0, 72\% removal was reached by carbonate precipitation while 225 hydroxide precipitation brought about 59\% removal leading to residual cobalt of $3.6 \mathrm{mM}$ and 5.2 
$\mathrm{mM}$, respectively. At $\mathrm{pH} 9.0$, the removal efficiency significantly increased using the carbonate and hydroxide precipitants achieving almost complete removal. At $\mathrm{pH} 11.0$, the highest removal of cobalt (100\%) was attained for both studied precipitants conforming to the standard set for cobalt. $100 \%$ cobalt removal was also achieved at $\mathrm{pH}$ values of 8.0 to 10.0 owing to $\mathrm{Co}(\mathrm{OH})_{2}$ precipitation [22]. $\mathrm{CoCO}_{3}$ and $\mathrm{Co}(\mathrm{OH})_{3}$ can be produced in an acidic and moderate intensity alkaline solution in a carbonate or bicarbonate system. According to Lin et al. [23], $\mathrm{Co}(\mathrm{OH})_{2}$ is usually formed in strong alkaline solution. In this present study, it was concluded that cobalt removal increased with increasing solution $\mathrm{pH}$. Qasem et al. [24] affirmed that chemical precipitation process efficiency is improved at higher $\mathrm{pH}$ range from 9.0 to 11.0.

The generated sludge volume at 30 min by the single cobalt system was observed to determine the settleability of the sludge at different $\mathrm{pH}$ values under identical operating conditions depicted in Fig. 4a. For carbonate precipitation, the remaining sludge volume was found to increase when $\mathrm{pH}$ increased from 7.0 to 11.0 and decreased significantly at $\mathrm{pH} 12.0$. This probably shows that the sludge particles are denser and more compact when the $\mathrm{pH}$ approaches neutral condition causing higher settleability and faster settling rate as presented in Fig. 4b. Likely cobalt carbonate exists at $\mathrm{pH} 7.0$ showing significant decrease in the settleability from $\mathrm{pH}$ 8.0. $\mathrm{CoCO}_{3}$ occurs at $\mathrm{pH}$ range of 6.9 to 7.5 as reported by Guo et al. [25]. Another study of Guo et al. [26] confirmed its existence at $\mathrm{pH}$ 7.10-7.25. The cobalt precipitate formed at $\mathrm{pH} 11.0$ was observed to be black in color which is probably due to $\mathrm{Co}_{3} \mathrm{O}_{4}$ precipitation as described by Uddin and Baig [27]. Whilst at $\mathrm{pH}$ 12.0, brown precipitate was recovered which can be attributed to $\mathrm{CoOOH}$ precipitation $[28,29]$. The change in cobalt species at different $\mathrm{pH}$ levels is possibly caused by oxidation [23]. For hydroxide precipitation, there was a great increase in the remaining sludge from $\mathrm{pH} 8.0$ to $\mathrm{pH}$ 9.0. A decreasing sludge volume was then observed from $\mathrm{pH} 9.0$ to 12.0. These differences in the 
249 sludge volume produced may be attributed to the type of precipitates formed, particle size, and 250 particle density as divulged by Lacson et al. [30]. On the other hand, copper was easily removed 251 using both carbonate and hydroxide precipitants as described in Figure 3b. Precipitation reactions 252 of copper are shown below:

253 based on the stoichiometric reaction presented as Eq. (22). The excess carbonate used possibly 257 caused the high removal efficiency of the copper in the single system. This was possibly brought 258 about by greater amount of carbonate ions interacting with the target copper ions. In addition, 259 precipitation starts at $\mathrm{pH} 6.0$ and all copper was precipitated out at $\mathrm{pH} 7.0$ for pure copper solution with $150 \mathrm{mg} \mathrm{L}^{-1}$ of concentration [31]. A cationic metal is generally mostly dissolved at relatively 261 low $\mathrm{pH}$ and becomes mostly sorbed at higher $\mathrm{pH}$ values as $\mathrm{pH}$ increases through a critical range 262 1-2 $\mathrm{pH}$ units wide. The high removal obtained in this system might also be due to precipitation 263 and adsorption mechanisms most especially at higher $\mathrm{pH}$ levels. Copper possibly formed copper264 bearing precipitates initially and the remaining copper in the solution was adsorbed on the surface 265 of the precipitates formed in the system causing no residual copper left in the solution [32]. This 266 occurrence could be due to electrostatic attraction and ligand exchange [33,34]. Furthermore, 267 copper carbonate precipitates are known to have appreciable amount of positive surface charges 268 ascribed to high level of particles' zeta potential. When the solution $\mathrm{pH}$ is gradually elevated, these 269 positive surface charges are suddenly reduced and finally shifted to negative surface charge when 270 the $\mathrm{pH}$ reaches higher than 7.5 [31]. This explains the possible phenomenon occurring in the single 271 copper system using carbonate precipitation. At $\mathrm{pH}$ 12.0, there was an observed decrease in the 
272 removal of copper using hydroxide which is probably caused by the re-dissolution of the

273 precipitate in the solution and/or desorption of copper from the copper-bearing precipitate. With

274 respect to the stoichiometry of the reaction shown in Eq. (23), the required $\left[\mathrm{OH}^{-}\right] /\left[\mathrm{Cu}^{2+}\right] \mathrm{molar}^{2}$

275 ratio represents a hydroxide concentration $60 \%$ below the stoichiometric requirement which is

276 affected by $\mathrm{pH}$ inducing copper precipitation. Similar results were obtained when hydroxide

277 precipitation was used to treat single copper system reaching greater than $97 \%$ removal.

278 For carbonate precipitation, $\mathrm{SV}_{30}$ ranges from about 140 to $220 \mathrm{~mL}$ per liter of mixed copper 279 and precipitant solution while about 70 to $180 \mathrm{~mL}$ per liter was observed for hydroxide 280 precipitation as depicted in Fig. 4c. Malachite, $\mathrm{Cu}_{2}(\mathrm{OH})_{2} \mathrm{CO}_{3}$, dominates in the copper solution at $281 \mathrm{pH}$ between 7.0 and 8.0. It was also observed by Pérez Sánchez et al. [35] that malachite exists at $282 \mathrm{pH}$ up to 10.3. This could explain the similar sludge volume generated from $\mathrm{pH}$ values of 7.0 to 28310.0 in the single copper system. At $\mathrm{pH} 11.0$, the $\mathrm{SV}_{30}$ significantly decreased possibly due to 284 azurite formation. At $\mathrm{pH}$ values between 6.0 to 7.0 and 10.3 to 14.0 , azurite, $\mathrm{Cu}_{3}(\mathrm{OH})_{2}\left(\mathrm{CO}_{3}\right)_{2}$, 285 could be the dominating species making it amphoteric. Black precipitate was observed at $\mathrm{pH} 12.0$ 286 which can be associated with $\mathrm{CuO}$ precipitation occurring at $\mathrm{pH}>10.3$. At $\mathrm{pH} 7.0$ and 8.0 using 287 hydroxide precipitation, $\mathrm{Cu}(\mathrm{OH})_{2}$ is the predicted precipitate which exists at $\mathrm{pH}$ values ranging 288 from 5.5 to 10.3 [35]. This precipitate is also said to exist at intermediate $\mathrm{pH}$ levels typically in the $289 \mathrm{pH}$ range of 6.5-12.0 [18]. Minimal solubility of metal hydroxides leading to higher probability of 290 precipitation is achieved at an approximate $\mathrm{pH}$ of $9.5-10.0[36,37] . \mathrm{Cu}(\mathrm{OH})_{2}$ is possibly formed at $291 \mathrm{pH} 9.0$ and 10.0 exhibiting larger particle size affecting the sludge volume after 30 min. Grayish 292 precipitate was formed at $\mathrm{pH} 11.0$ while black precipitate was generated at $\mathrm{pH} 12.0$ which could 293 probably be caused by $\mathrm{CuO}$ precipitation [38]. 
To further validate the results drawn, the solubility products of $2.20 \times 10^{-20}$ for $\mathrm{Cu}(\mathrm{OH})_{2}$ and $1.40 \times 10^{-10}$ for $\mathrm{CuCO}_{3}$ were used to calculate the $\mathrm{pH}$ and carbonate concentration for precipitating

297 Precipitation $\mathrm{Cu}(\mathrm{OH})_{2}$ and $\mathrm{CuCO}_{3}$ occurs when the solubility products are exceeded as shown 298 below.

$\left[\mathrm{Cu}^{2+}\right]\left[\mathrm{OH}^{-}\right]^{2}=\left(\frac{800}{63.55} \times 10^{-3}\right)\left(10^{-14+\mathrm{pH}}\right)^{2} \geq 10 \times 2.20 \times 10^{-20}$

$300\left[\mathrm{Cu}^{2+}\right]\left[\mathrm{CO}_{3}{ }^{2-}\right]=\left(\frac{800}{63.55} \times 10^{-3}\right)\left(\mathrm{CO}_{3}{ }^{2-}\right) \geq 10 \times 1.40 \times 10^{-10}$

301 Where 63.55 is the molecular weight of copper $\left(\mathrm{g} \mathrm{mol}^{-1}\right), 10$ is the assumed saturation index for 302 homogeneous precipitation, $2.20 \times 10^{-20}$ is the solubility product of $\mathrm{Cu}(\mathrm{OH})_{2}$, and $1.40 \times 10^{-10}$ is 303 the solubility product of $\mathrm{CuCO}_{3}$.

304 Thus, $\mathrm{pH} \geq 5.62$ is the starting $\mathrm{pH}$ for $\mathrm{Cu}(\mathrm{OH})_{2}$ precipitation whereas $\left[\mathrm{CO}_{3}{ }^{2-}\right] \geq 1.11 \times 10^{-7} \mathrm{M}$ 305 is the carbonate concentration needed for $\mathrm{CuCO}_{3}$ precipitation. In an open atmospheric carbonate 306 system, carbonate concentration is given by the equation:

$307 \quad\left[\mathrm{CO}_{3}{ }^{2-}\right]=\frac{\left[\mathrm{H}_{2} \mathrm{CO}_{3}{ }^{*}\right] \cdot \mathrm{K}_{\mathrm{a}, 1} \cdot \mathrm{K}_{\mathrm{a}, 2}}{\left[\mathrm{H}^{+}\right]^{2}}$

308 Where $\left[\mathrm{H}_{2} \mathrm{CO}_{3}{ }^{*}\right]=\left[\mathrm{CO}_{2(\mathrm{aq})}\right]=10^{-5} \mathrm{M}, \mathrm{K}_{\mathrm{a}, 1}=10^{-6.3}$, and $\mathrm{K}_{\mathrm{a}, 2}=10^{-10.3}$

309 Substituting all the values and rearranging, we get $\left[\mathrm{H}^{+}\right] \leq 4.76 \times 10^{-8}$, and $\mathrm{pH} \geq 7.32$. Thus, the 310 calculations done and analyses suggest that homogeneous copper precipitation of $\mathrm{Cu}(\mathrm{OH})_{2}$ cannot 311 take place until $\mathrm{pH}$ is greater than 5.62 for $12.6 \mathrm{mM} \mathrm{Cu}^{2+}$ in an open atmospheric condition which 312 is roughly $1.7 \mathrm{pH}$ unit lower than the $\mathrm{CuCO}_{3}$ precipitation $(\mathrm{pH} \geq 7.32)$. The results affirm that 313 precipitation occurred at these $\mathrm{pH}$ values. However, the actual carbonate concentration used in the 314 treatment of copper in the system is greater than the calculated value. With this, copper could be 315 precipitated at lower $\mathrm{pH}$ level compared to cobalt precipitation. 
The behavior of $\mathrm{Co}(\mathrm{II})$ in the co-contaminated system was also studied in terms of the effect of $317 \mathrm{pH}$ on its removal in the presence of $\mathrm{Cu}(\mathrm{II})$ as presented in Fig. 5a. For both precipitants, increasing the $\mathrm{pH}$ increased the cobalt co-removal and co-precipitation with copper. Using sodium carbonate as precipitant, cobalt was removed to over $99 \%$ at $\mathrm{pH} 9.0$. The same result was achieved by Safitri et al. [39] in treating cobalt in a multi-component heavy metal system reaching over 99\% removal at $\mathrm{pH}$ 9.0. Cobalt removal efficiency reached greater than $99 \%$ at $\mathrm{pH}$ levels above 9.0. The optimum $\mathrm{pH}$ for maximum cobalt co-removal in the system is about $\mathrm{pH} 10.0$ for both precipitants 323 utilized similar with the results in the single cobalt system. The co-removal and co-precipitation 324 of cobalt with copper was found to be greatly dependent on $\mathrm{pH}$ similar as the result presented by 325 Sun et al. [34]. The co-removal of chromium through copper precipitation also depended highly 326 on the solution $\mathrm{pH}$ of the reaction system which confirms the dependency of metal co-removal on 327 solution $\mathrm{pH}$ [34]. As shown in Fig. 5b, copper was found to be removed easily at all the $\mathrm{pH}$ range 328 studied in the co-contaminated system. Copper removal showed a similar trend with that of single 329 copper system. In the co-contaminated system, copper removal also decreased at $\mathrm{pH} 12.0$ possibly due to re-dissolution in the reaction system [40]. It was significantly observed that the co-existence 331 of cobalt did not affect the removal efficiency of copper in the two-component system.

332 For sodium carbonate precipitant, the $\mathrm{SV}_{30}$ increased from $\mathrm{pH} 7.0$ to $\mathrm{pH} 10.0$ then slightly 333 decreased at $\mathrm{pH}$ 11.0. At $\mathrm{pH}$ 12.0, a great decrease was observed in Fig. 5c. For hydroxide 334 precipitation, around $200-500 \mathrm{~mL} \mathrm{~L}^{-1}$ of $\mathrm{SV}_{30}$ was observed. The sludge volume generated in the 335 co-contaminated system was observed to be greater than the single systems of cobalt and copper 336 pollutants at all $\mathrm{pH}$ values. This could be associated with the greater total metal concentration, and 337 higher amount of precipitant dosage used to treat two metals in the system. The total metal 338 concentration $([\mathrm{M}]=[\mathrm{Co}]+[\mathrm{Cu}])$ is about $25.2 \mathrm{mM}(12.6 \mathrm{mM} \mathrm{Co}$ and $12.6 \mathrm{mM} \mathrm{Cu})$. Thus, the 
necessary carbonate and hydroxide concentrations also increased probably causing greater sludge volume and slower settleability of precipitates (lower SSR) in the reaction system due to possible trapping of water molecules in the formed precipitates (Fig. 5d) [30]. Higher precipitant dosage as well as higher $\mathrm{pH}$ values lead to increase in nucleation number of particles and decrease in particle size, accordingly, causing slower sedimentation time in the precipitation system [9]. The behavior of the precipitates formed is seen to vary at different $\mathrm{pH}$ levels for both precipitants used.

\subsection{Effect of precipitant-to-metal ratio}

Based on the crystallization theory, particle nucleation and growth are dependent on the supersaturation level of the solution [41]. Higher saturation number yields greater particle nucleation rate. Precipitant concentration is also significant in the chemical precipitation process. Low precipitant concentration leads to growth of particles on pre-existing solids in the system. On the other hand, high precipitant concentration tends to promote rapid formation of new solid particles leading to increase in the particle number and reduction of the particle size [9]. As the precipitant concentration increases, the precipitant-to-metal ratio also increases. To establish the precipitant-to-metal molar ratio necessary to remove cobalt and copper in the single- and cocontaminated system, several experiments were conducted using 0.5-2.5 molar ratios under similar conditions. The highest cobalt removal $(98 \%)$ was achieved with $\left[\mathrm{CO}_{3}{ }^{2-}\right] /\left[\mathrm{Co}^{2+}\right]$ ratio of 1.5 with reaction $\mathrm{pH}$ of about 8.5 in the single system as depicted in Fig. 6a. Based on the stoichiometric reaction (Eq. (10)), the carbonate-to-cobalt ratio needed to reach almost complete removal was $50 \%$ above the stoichiometric requirement. There was no further increase observed when the $\left[\mathrm{CO}_{3}{ }^{2-}\right] /\left[\mathrm{Co}^{2+}\right]$ ratio was further increased up to 2.5 . On the other hand, $\left[\mathrm{OH}^{-}\right] /\left[\mathrm{Co}^{2+}\right]$ ratio of 2.0 showed the highest cobalt removal efficiency (84\%) at the same reaction $\mathrm{pH}$. This is affirmed from 
362 the stoichiometry of the given reaction as Eq. (11). However, $\left[\mathrm{OH}^{-}\right] /\left[\mathrm{Co}^{2+}\right]$ ratio of 1.5 to 2.5

363 displayed no significant increase in the reduction of cobalt. Thus, $\left[\mathrm{OH}^{-}\right] /\left[\mathrm{Co}^{2+}\right]$ ratio of 1.5 was

364 considered as the optimum value to treat cobalt in the single system.

365 Since the cobalt concentration was set at a specific value, the increase in $\left[\mathrm{CO}_{3}{ }^{2-}\right] /\left[\mathrm{Co}^{2+}\right]$ molar

366 ratio will lead to a higher $\mathrm{CO}_{3}{ }^{2-}$ ion concentration. Therefore, this leads to higher supersaturation

367 according to Eq. (27). Moreover, lower radius of critical nucleation is caused by an increase in

368 supersaturation which leads to easier nucleation based on the Gibbs-Thompson equation depicted

369 as Eq. (28) [42]. Accordingly, precipitates with lower particle size will be formed under similar

370 metal content as also mentioned above [26].

$371 \quad S=\sqrt{\frac{C_{m} \cdot C_{s}}{K_{s p}(m s)}}$

372 Where $\mathrm{S}$ is supersaturation; $\mathrm{C}_{\mathrm{m}}$ is the concentration of metal ions; $\mathrm{C}_{\mathrm{s}}$ is the precipitant ion

373 concentration; $\mathrm{K}_{\mathrm{sp}(\mathrm{ms})}$ is the precipitation solubility product constant.

$374 \quad \ln \frac{C}{C_{s}}=\frac{2 \sigma \cdot M}{R T \rho \cdot r_{c r i t}}$

375 Where $\mathrm{C}$ is the concentration of the solution, $\mathrm{C}_{\mathrm{s}}$ is the supersaturation, $\sigma$ is the surface tension, $\mathrm{M}$

376 is the molar mass, $\mathrm{R}$ is the thermodynamic constant, $\mathrm{T}$ is the thermodynamic temperature, $\rho$ is the

377 density, and $r_{\text {crit }}$ is the critical radius.

378 At $\left[\mathrm{CO}_{3}{ }^{2-}\right] /\left[\mathrm{Co}^{2+}\right]$ of 1.5 to 2.5 , the sludge volume did not significantly change as well as the 379 reaction $\mathrm{pH}($ about $\mathrm{pH}$ 8.5) as shown in Figs. 7a and 6a. It can be deduced that at this range the 380 precipitate formed is of the same species which could possibly be $\mathrm{Co}(\mathrm{OH})_{2}$ instead of $\mathrm{CoCO}_{3}$ 381 despite using carbonate system. $\mathrm{CoCO}_{3}$ might be oxidized to $\mathrm{Co}_{3} \mathrm{O}_{4}$ followed by reduction to form $382 \mathrm{Co}(\mathrm{OH})_{2}$ precipitate $[23] . \mathrm{CoCO}_{3}$ is possibly precipitated at $\left[\mathrm{CO}_{3}{ }^{2-}\right] /\left[\mathrm{Co}^{2+}\right]$ of $0.5\left(\left[\mathrm{CO}_{3}{ }^{2-}\right]=6.3 \mathrm{x}\right.$ $38310^{-3} \mathrm{M}$ ) brought about by the moderately alkaline $\mathrm{pH}$ (below $\mathrm{pH} 8.0$ ). 0.5 as $\left[\mathrm{CO}_{3}{ }^{2-}\right] /\left[\mathrm{Co}^{2+}\right]$ ratio 384 is more than enough to form $\mathrm{CoCO}_{3}$ in the system based on the calculated necessary $\mathrm{CO}_{3}{ }^{2-}$ 
concentration in Section 3.1.1. However, the $\mathrm{pH}$ of the solution is still a governing factor in the type of precipitate forming in the reaction system. On the other hand, $\left[\mathrm{OH}^{-}\right] /\left[\mathrm{Co}^{2+}\right]$ molar ratio of 0.5 produced low sludge volume which may be associated with the low removal efficiency of cobalt in the reaction system.

We can see in Fig. 6b that there was no significant effect observed in the removal of copper under all the $[\mathrm{P}] /[\mathrm{M}]$ ratios studied for both precipitants in the study. This might be possibly caused by the $\mathrm{pH}$ used in the reaction system (around $\mathrm{pH}$ 8.0). The reaction $\mathrm{pH}$ for all the studied ratio is in the range of 7.5 to 8.5 . This can be affirmed based from the calculated starting $\mathrm{pH}$ wherein $\mathrm{Cu}(\mathrm{OH})_{2}$ and $\mathrm{CuCO}_{3}$ undergo precipitation. The sludge volume at 30 min was also determined as well as the settling rate of the sludge formed at different $[\mathrm{P}] /[\mathrm{M}]$ ratios presented in Figs. 7c and 7d. The discrepancies in the sludge volume generated together with the sludge settling rate is possibly affected by the differences in the reaction $\mathrm{pH}$ in the single copper system.

For the co-contaminated system, cobalt reached maximum removal at $\left[\mathrm{CO}_{3}{ }^{2-}\right] /[\mathrm{M}]$ and $\left[\mathrm{OH}^{-}\right] /[\mathrm{M}]$ of 2.0 presented in Fig. 8a. There is no further increase observed when both molar ratios are increased to 2.5. For the single cobalt system, $\left[\mathrm{CO}_{3}{ }^{2-}\right] /\left[\mathrm{Co}^{2}\right]$ and $\left[\mathrm{OH}^{-}\right] /\left[\mathrm{Co}^{2+}\right]$ of 1.5 were found to be the optimal $[\mathrm{P}] /[\mathrm{M}]$ conditions which are lower than that of the co-contaminated system. Greater $[\mathrm{P}] /[\mathrm{M}]$ ratio is needed to treat cobalt in the co-contaminated system due to the fact this system contains two metals leading to higher supersaturation which makes it harder to precipitate. Moreover, there could be a competition between the cobalt and copper ions to interact with carbonate and hydroxide ions affecting the precipitation efficiency. Similar trend with the single copper system was found for the treatment of copper in the co-contaminated system seen in Fig. $8 \mathrm{~b}$. For the carbonate precipitation system, $\left[\mathrm{CO}_{3}{ }^{2-}\right] /[\mathrm{M}]$ of 1.0 showed the greatest amount of sludge volume generated. On the other hand, $\left[\mathrm{OH}^{-}\right] /[\mathrm{M}]$ of 1.5 generated the largest $\mathrm{SV}_{30} . \mathrm{SV}_{30}$ 
recorded as observed in Fig. 8c are 450 to 620 and 120 to $500 \mathrm{~mL} \mathrm{~L}^{-1}$ for carbonate and hydroxide precipitants, respectively, greater than that of the single cobalt and copper systems. In both single copper and co-contaminated systems, increasing the $[\mathrm{P}] /[\mathrm{M}]$ ratio did not show any significant trend with the settleability of the precipitates in the reaction system depicted in Figs. $7 \mathrm{~d}$ and $8 \mathrm{~d}$. Precipitant-to-metal ratio was found to be at optimum value of 1.2 in the study conducted by Mahasti et al. [43]. In contrary, $[\mathrm{P}] /[\mathrm{M}]$ ratio necessary for treatment of cobalt and copper varied for the single- and co-contaminated wastewater stream in this study.

\subsection{Effect of precipitant type}

Cobalt removal by carbonate precipitation is significantly higher than that of hydroxide precipitation at weaker alkaline to neutral conditions in both single- and co-contaminated systems as shown in Fig. 9a. The precipitating agents used for removing cobalt from the simulated wastewater exhibited significant influence on the removal efficiency and resulting sludge in the system. Fig. 10 shows the supernatant volume for all the systems studied after 30 min of sludge settling. It was also found that the sludge formed by carbonate precipitation exhibits slower settling rate (lower supernatant volume) than that of hydroxide precipitation for all the $\mathrm{pH}$ values and $[\mathrm{P}] /[\mathrm{M}]$ ratio studied for both systems. This may have been caused by less dense sludge particles and smaller particle size [30]. No general trend was found for the sludge volume formed from single cobalt and single copper systems. The results also show that even at increasing $[\mathrm{P}] /[\mathrm{M}]$ ratios carbonate precipitation displayed better removal efficiency (lower residual Co) than hydroxide precipitation presented in Fig. 9b. Carbonate precipitation treatment can occur at pH values lower than that of hydroxide precipitation [44] which was evident in this study. Hydroxide system was found to be more effective in reducing the soluble zinc concentration than that of the 
431 carbonate system in the study conducted by Patterson et al. [44]. Contrarily, carbonate system was

432 found to be more effective and efficient in this study for the treatment of cobalt and copper in

433 single- and co-contaminated streams. In the literature, hydroxide precipitation produces larger

434 volumes of low-density sludge [37]. However, this study observed that the carbonate precipitation

435 led to lower sludge density than the sludge generated by hydroxide precipitation. When particle

436 recovery and reuse are added advantage, sodium carbonate is also better than sodium hydroxide

437 as precipitant.

438

439 4. Conclusions

440 The behavior of cobalt in the single- and co-contaminated system showed similar removal at $\mathrm{pH}$

441 value of 10.0. Copper in the single system was easily removed in the system at $\mathrm{pH}$ values of 7.0-

$442 \quad 12.0$ which may be due to precipitation-adsorption mechanism at $\mathrm{pH}$ values higher than 7.5.

443 Copper probably forms initial copper-bearing precipitates and the remaining copper in the

444 simulated wastewater stream is adsorbed on the surface of the precipitate formed in the system

445 resulting to its complete removal. Precipitant-to-metal ratio necessary to treat cobalt varied for the

446 single- and co-contaminated systems for both precipitants used. There was no significant effect on

447 the copper system possibly due to excess precipitant dosage. The co-existence of cobalt did not

448 affect the removal of copper in the co-contaminated wastewater stream. Carbonate and hydroxide

449 precipitation systems are effective treatment methods in dealing with the metal pollutants

450 contained in electroplating wastewater leading to high removal efficiency. In addition, carbonate

451 precipitation was found to be a more effective and efficient treatment alternative to hydroxide

452 precipitation, and soluble cobalt and copper can be removed from the wastewater streams using

453 soda ash. One of the advantages of carbonate system with the hydroxide system was the operation 
454 at lower $\mathrm{pH}$ values typically around 7.0-8.0. In terms of sludge volume, carbonate system had 455 added advantage when the additional target is particle recovery and reuse.

456 Declarations

457 Availability of data and materials

458 All data generated or analyzed in this work are available from the corresponding author on 459 reasonable request.

460

461 Competing interests

462 The authors declare that they have no known competing financial interests.

463

$464 \quad$ Funding

465 This work was supported by the Ministry of Science and Technology, Taiwan with grant no. 466 MOST 107-2221-E-041-001-MY3 and MOST 106-2622-E006-037-CC2.

467

468 Authors' contributions

469 Khyle Glainmer N. Quiton conceptualized the study and carried out the experimental studies. 470 Ming-Chun Lu provided conceptual and technical guidance for all the aspects of the work. Yao471 Hui Huang commented, reviewed, and approved its completion. All authors read and approved the 472 final manuscript.

473

474 Acknowledgements

475 The authors would like to thank the Ministry of Science and Technology, Taiwan (MOST 107476 2221-E-041-001-MY3 and MOST 106-2622-E006-037-CC2) for the financial support with this 
477 work. Special thanks to Engr. Carl Francis Lacson and Ma. Antonette Rubios for their valuable 478 insights during the conduct of this work.

479 Authors' information

480 Department of Chemical Engineering, Sustainable Environment Research Center, National 481 Cheng Kung University, Tainan 701, Taiwan

482 Khyle Glainmer N. Quiton \& Yao-Hui Huang

483

484

485

Department of Environmental Engineering, National Chung Hsing University, Taichung 40227, Taiwan

486 Ming-Chun Lu

487

488

References

489 [1] Qiu B, Tao X, Wang H, Li W, Ding X, Chu H. Biochar as a low-cost adsorbent for 490 aqueous heavy metal removal: a review. J Anal Appl Pyrolysis. 2021;155:105081.

491 [2] Zhang Y, Duan X. Chemical precipitation of heavy metals from wastewater by using the 492 synthetical magnesium hydroxy carbonate. Water Sci Technol. 2020;81:1130-6.

493

[3] Awual MR, Hasan MM, Islam A, Asiri AM, Rahman MM. Optimization of an innovative composited material for effective monitoring and removal of cobalt(II) from wastewater. $\mathbf{J}$ Mol Liq. 2020;298:112035.

496 [4] Saad DR, Alismaeel ZT, Abbar AH. Cobalt removal from simulated wastewaters using a 497 novel flow-by fixed bed bio-electrochemical reactor. Chem Eng Process - Process Intensif. 2020;156:108097. 
detection and extraction of copper ions using $\mathrm{ZnSe}-\mathrm{CdSe} / \mathrm{SiO} 2$ core-shell nanomaterial. J

501

502

503

504

505

506

507

508

509

510

511

512

513

514

515

516

517

518

519

520

521

522 Ind Eng Chem. 2019;73:118-27.

[6] Liu H, Cui S, Shi F, Pu S. A diarylethene based multi-functional sensor for fluorescent detection of $\mathrm{Cd} 2+$ and colorimetric detection of $\mathrm{Cu}^{2+}$. Dye Pigment. 2019;161:34-43.

[7] Godiya CB, Cheng X, Li D, Chen Z, Lu X. Carboxymethyl cellulose/polyacrylamide composite hydrogel for cascaded treatment/reuse of heavy metal ions in wastewater. J Hazard Mater. 2019;364:28-38.

[8] Sharma AK, Priya, Kaith BS, Singh A, Isha, Vipula, et al. Enzymatic construction of quinine derivative of dextrin/PVA based hybrid gel film for the simultaneous detection and removal of copper and lead ions in real water samples. Chem Eng J. 2020;382:122891.

[9] Chen Q, Yao Y, Li X, Lu J, Zhou J, Huang Z. Comparison of heavy metal removals from aqueous solutions by chemical precipitation and characteristics of precipitates. J Water Process Eng. 2018;26:289-300.

[10] Duan C, Ma T, Wang J, Zhou Y. Removal of heavy metals from aqueous solution using carbon-based adsorbents: A review. J Water Process Eng. 2020;37:101339.

[11] Junuzovic H, Begic S, Selimovic A, Dozic A, Cvrk R, Ahmetovi M. Efficiency of carbonate precipitation and removal of copper and nickel ions from their monocomponent and two-component aqueous solutions. Int J Res Appl Sci Biotechnol. 2019;06:11-5.

[12] Wołowiec M, Komorowska-kaufman M, Pruss A, Rzepa G, Bajda T. Removal ofheavy metals and metalloids from water using drinking water treatment. Minerals. 2019;9:1-17.

[13] Oustadakis P, Agatzini-Leonardou S, Tsakiridis PE. Nickel and cobalt precipitation from sulphate leach liquor using MgO pulp as neutralizing agent. Miner Eng. 2006;19:1204-11. 
523 [14] Djoudi N, Le Page Mostefa M, Muhr H. Precipitation of cobalt salts for recovery in leachates. Chem Eng Technol. 2019;42:1492-9.

525 [15] Pang FM, Teng SP, Teng TT, Mohd Omar AK. Heavy metals removal by hydroxide precipitation and coagulation-flocculation methods from aqueous solutions. Water Qual Res J Canada. 2009;44:174-82.

[16] Popenda A. Effect of redox potential on heavy metals and As behavior in dredged sediments. Desalin Water Treat. 2014;52:3918-27.

[17] Wang T-H, Lin K-L. The Dissolution and supersaturation of $\mathrm{Zn}$ in the $\mathrm{Sn}-9 \mathrm{Zn}$ solder under current stressing. J Electron Mater. 2016;45:164-71.

[18] Cuppett JD, Duncan SE, Dietrich AM. Evaluation of copper speciation and water quality factors that affect aqueous copper tasting response. Chem Senses. 2006;31:689-97.

[19] Huang JH, Kargl-Simard C, Oliazadeh M, Alfantazi AM. pH-controlled precipitation of cobalt and molybdenum from industrial waste effluents of a cobalt electrodeposition process. Hydrometallurgy. 2004;75:77-90.

[20] Du H, Jiao L, Wang Q, Huan Q, Guo L, Si Y, et al. Morphology control of $\mathrm{CoCO}_{3}$ crystals and their conversion to mesoporous $\mathrm{Co}_{3} \mathrm{O}_{4}$ for alkaline rechargeable batteries application. Cryst Eng Comm. 2013;15:6101-9.

[21] Boguta P, Sokołowska Z. Zinc binding to fulvic acids: Assessing the impact of pH, metal concentrations and chemical properties of fulvic acids on the mechanism and stability of formed soluble complexes. Molecules. 2020;25:1297.

[22] Al-Shahrani SS. Treatment of wastewater contaminated with cobalt using Saudi activated bentonite. Alexandria Eng J. 2014;53:205-11.

[23] Lin S, Niu L, Pan X, Liang Z, Zhang T. Study on preparation and recovery of cobalt 
hydroxide and cobalt carbonate. Hydrometallurgy. 2020:105518.

547

[24] Qasem NAA, Mohammed RH, Lawal DU. Removal of heavy metal ions from wastewater: a comprehensive and critical review. Npj Clean Water. 2021;4.

[25] Guo M, Xi X, Li S, Li C, Nie Z, Xu K. Preparation of small-particle and high-density cobalt carbonate using a continuous carbonate precipitation method and evaluation of its growth mechanism. Materials (Basel). 2019;12:1-14.

[26] Guo M, Xi X, Li S, Long X, Nie Z, Xu K. A novel liquid precipitation route to synthesize high-quality cobalt carbonate with low chloride ions concentration. IOP Conf Ser Earth Environ Sci. 2019;295.

[27] Uddin MK, Baig U. Synthesis of $\mathrm{Co}_{3} \mathrm{O}_{4}$ nanoparticles and their performance towards methyl orange dye removal: characterisation, adsorption and response surface methodology. J Clean Prod. 2019;211:1141-53.

[28] Wu QD, Liu S, Yao SM, Gao XP. Electrochemical performance of cobalt hydroxide carbonate nanorods. Electrochem Solid-State Lett. 2008;11:215-8.

[29] Yang J, Hyodo H, Kimura K, Sasaki T. $\mathrm{Co}(\mathrm{OH})_{3}$ nanobelts: Synthesis, characterization and shape-preserved transformation to pseudo-single-crystalline $\mathrm{Co}_{3} \mathrm{O}_{4}$ nanobelts. Nanotechnology. 2010;21.

[30] Lacson CFZ, Lu MC, Huang YH. Fluoride-rich wastewater treatment by ballast-assisted precipitation with the selection of precipitants and discarded or recovered materials as ballast. J Environ Chem Eng. 2021;9:105713.

[31] Sun JM, Huang JC. Co-removal of hexavalent chromium through adsorption during copper precipitation. Water Sci Technol. 2004;50:201-8.

[32] Marchioretto MM, Bruning H, Rulkens W. Heavy metals precipitation in sewage sludge. 
Sep Sci Technol. 2005;40:3393-405.

570 [33] Sun JM, Zhao XH, Huang JC. Characterization of adsorbent composition in co-removal of hexavalent chromium with copper precipitation. Chemosphere. 2005;58:1003-10.

572 [34] Sun JM, Chang SY, Li R, Huang JC. Factors affecting co-removal of chromium through

573 copper precipitation. Sep Purif Technol. 2007;56:57-62. h

574 [35] Pérez Sánchez M, Barrera M, González S, Souto RM, Salvarezza RC, Arvia AJ.

575 Electrochemical behaviour of copper in aqueous moderate alkaline media, containing

[36] Blais JF, Djedidi Z, Cheikh RB, Tyagi RD, Mercier G. Metals precipitation from effluents: review. Pract Period Hazardous, Toxic, Radioact Waste Manag. 2008;12:13549.

[37] Fu F, Wang Q. Removal of heavy metal ions from wastewaters: a review. J Environ Manage. 2011;92:407-18.

[38] Phiwdang K, Suphankij S, Mekprasart W, Pecharapa W. Synthesis of CuO nanoparticles 584 by precipitation method using different precursors. Energy Procedia. 2013;34:740-5.

[39] Safitri N, Mubarok MZ, Winarko R, Tanlega Z. Recovery of nickel and cobalt as MHP from limonitic ore leaching solution: Kinetics analysis and precipitate characterization. AIP Conf Proc. 2018;1964:020030.

[40] Le VG, Vo DVN, Nguyen NH, Shih YJ, Vu CT, Liao CH, et al. Struvite recovery from swine wastewater using fluidized-bed homogeneous granulation process. J Environ Chem Eng. 2021;9:105019.

591 [41] Lutsko JF. How crystals form: A theory of nucleation pathways. Sci Adv. 2019;5:1-8. 
592 [42] Thanh NTK, Maclean N, Mahiddine S. Mechanisms of nucleation and growth of

593

594

595

596

597

598

599

600

601

602

603

604

605

606

607

608

601 nanoparticles in solution. Chem Rev. 2014;114:7610-30.

[43] Mahasti NNN, Shih YJ, Huang YH. Removal of iron as oxyhydroxide (FeOOH) from aqueous solution by fluidized-bed homogeneous crystallization. J Taiwan Inst Chem Eng. 2019;96:496-502.

[44] Patterson JW, Allen HE, Scala JJ. Carbonate precipitation for heavy metals pollutants. J Water Pollut Control Fed. 1977;49:2397-410.

9

.

62 


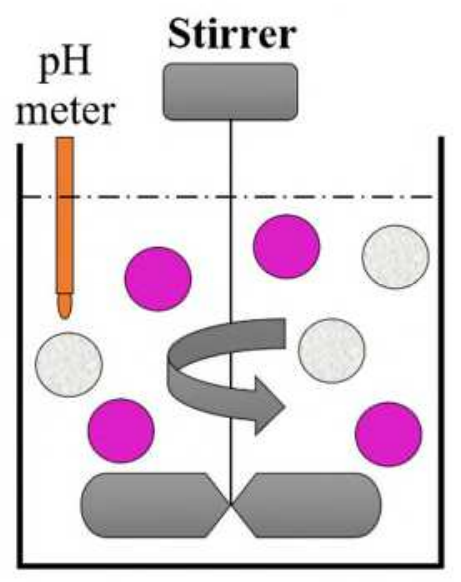

Single Cobalt System

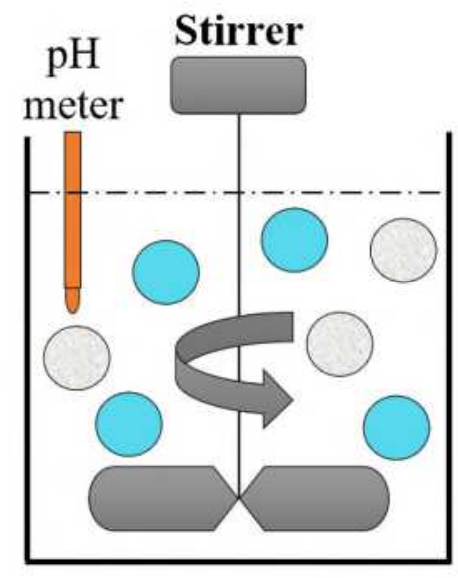

Single Copper System

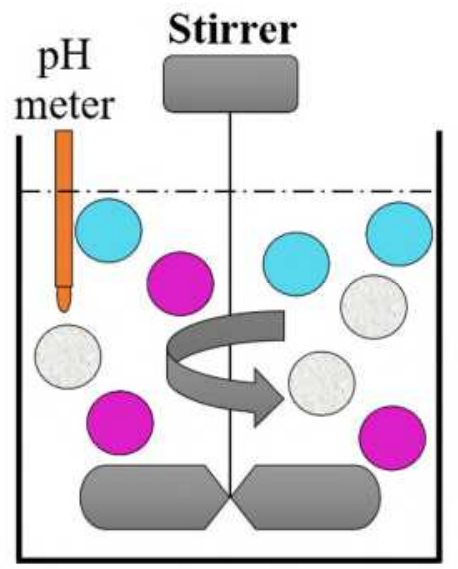

Co-contaminated System

Fig. 1. Experimental set-up for single and co-contaminated systems.

611

612

613

614

615

616

617

618

619

620 

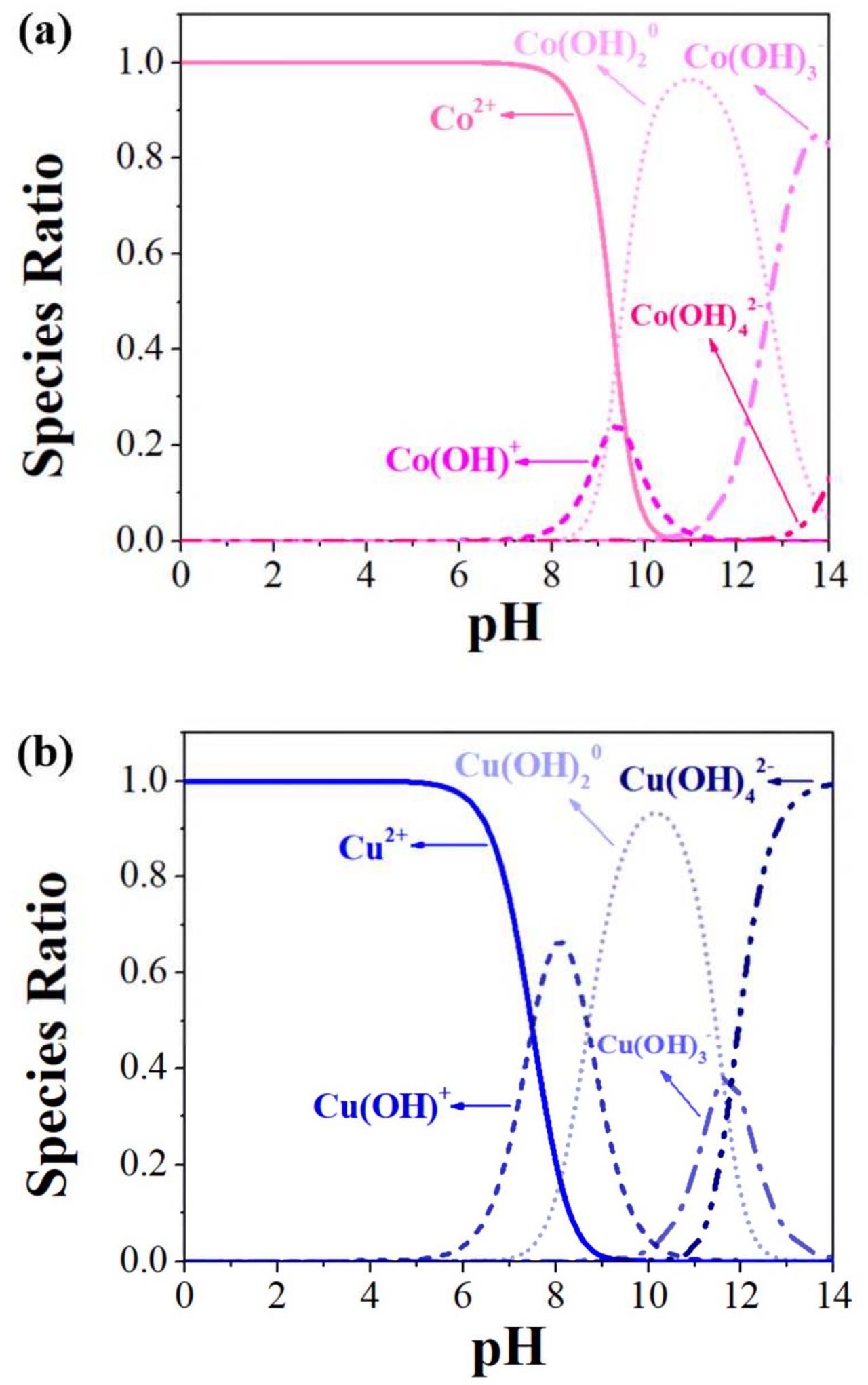

Fig. 2. Speciation of (a) cobalt and (b) copper for soluble hydro complexes in pure water. 

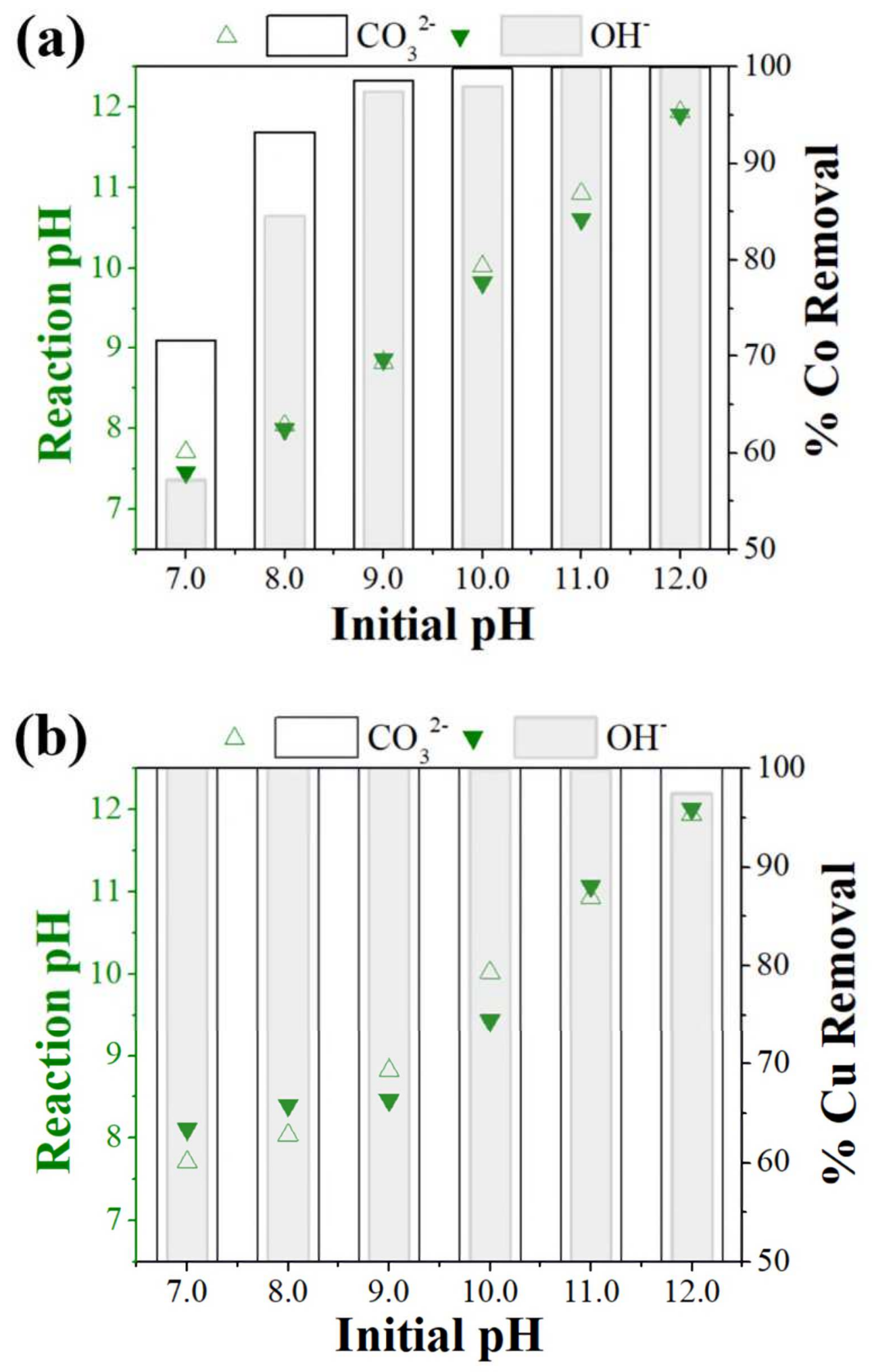

Fig. 3. Removal efficiency of (a) cobalt and (b) copper at different pH values using different precipitants (Conditions: $[\mathrm{Co}]_{\mathrm{o}}=[\mathrm{Cu}]_{\mathrm{o}}=12.6 \mathrm{mM} ; \mathrm{pH}=$ variable; $[\mathrm{P}] /[\mathrm{M}]=1.2$ ). 
(a)

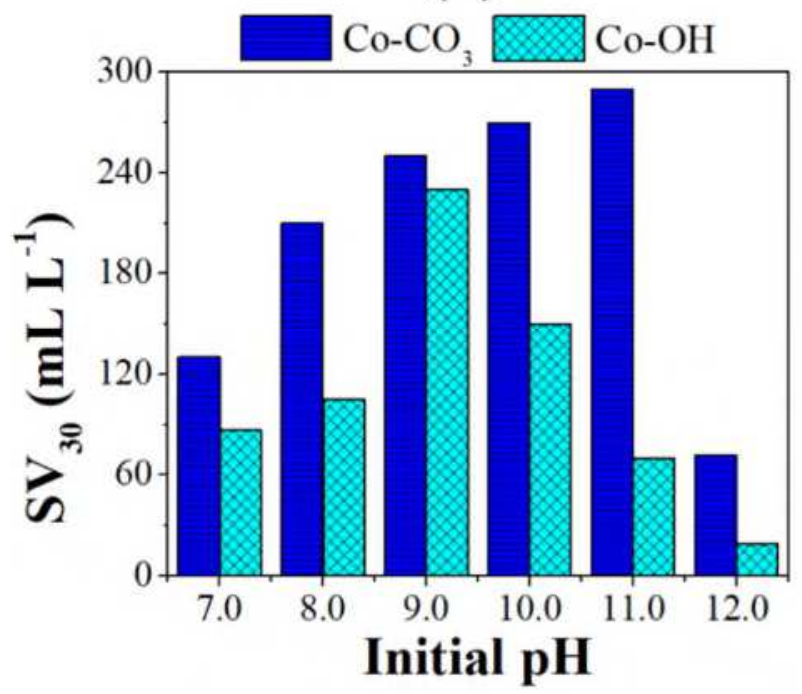

(b)

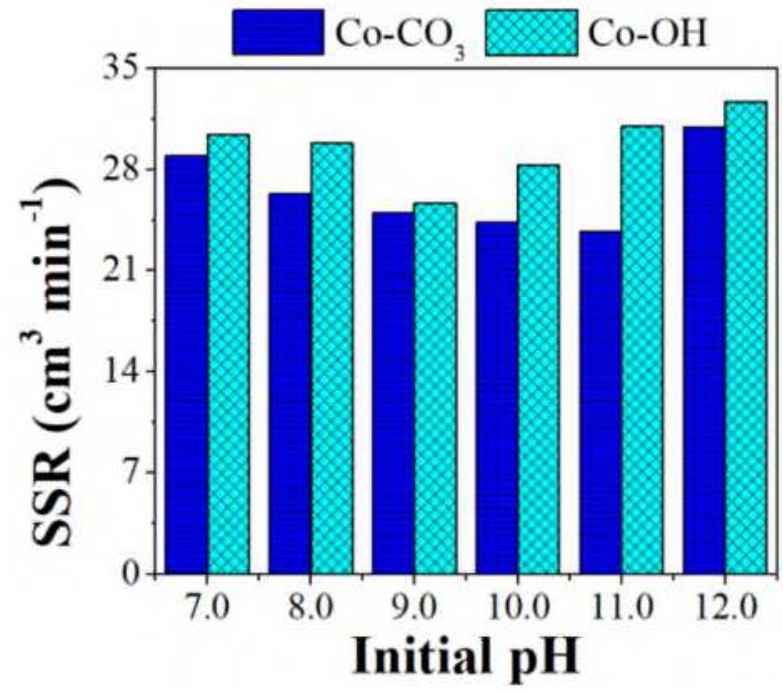

(c)

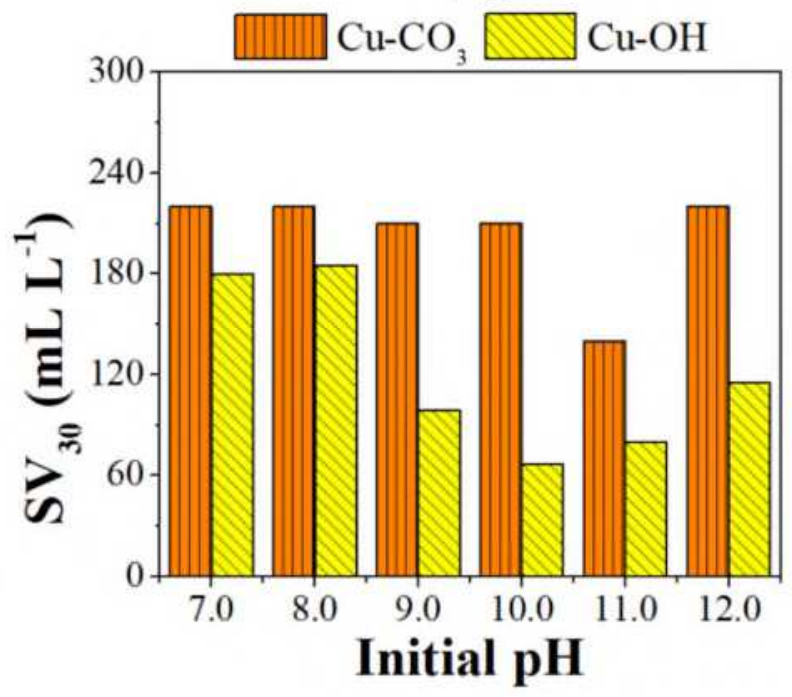

(d)

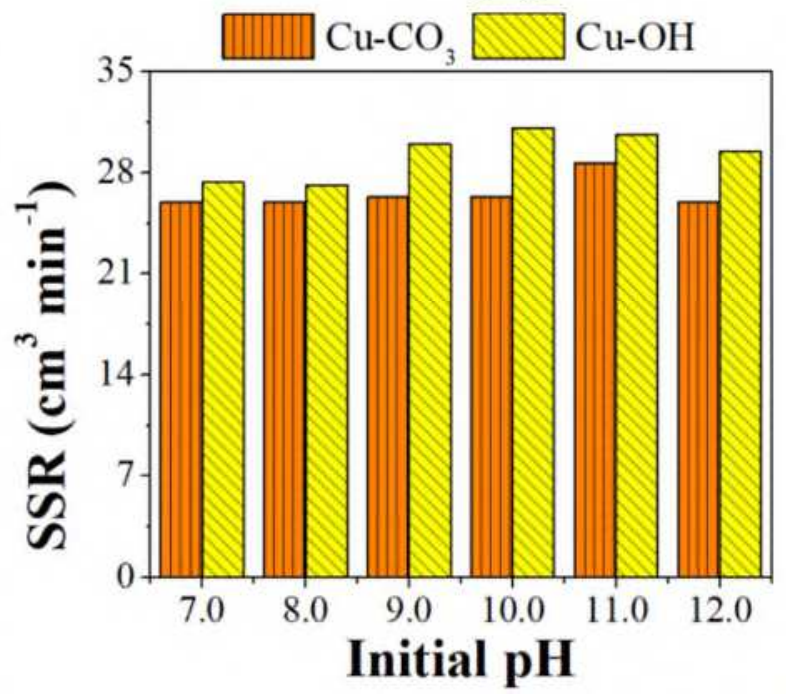

629 Fig. 4. Sludge volume at $30 \mathrm{~min}$ and sludge settling rate at different $\mathrm{pH}$ values for cobalt (a-b) and copper (c-d) using different precipitants. 

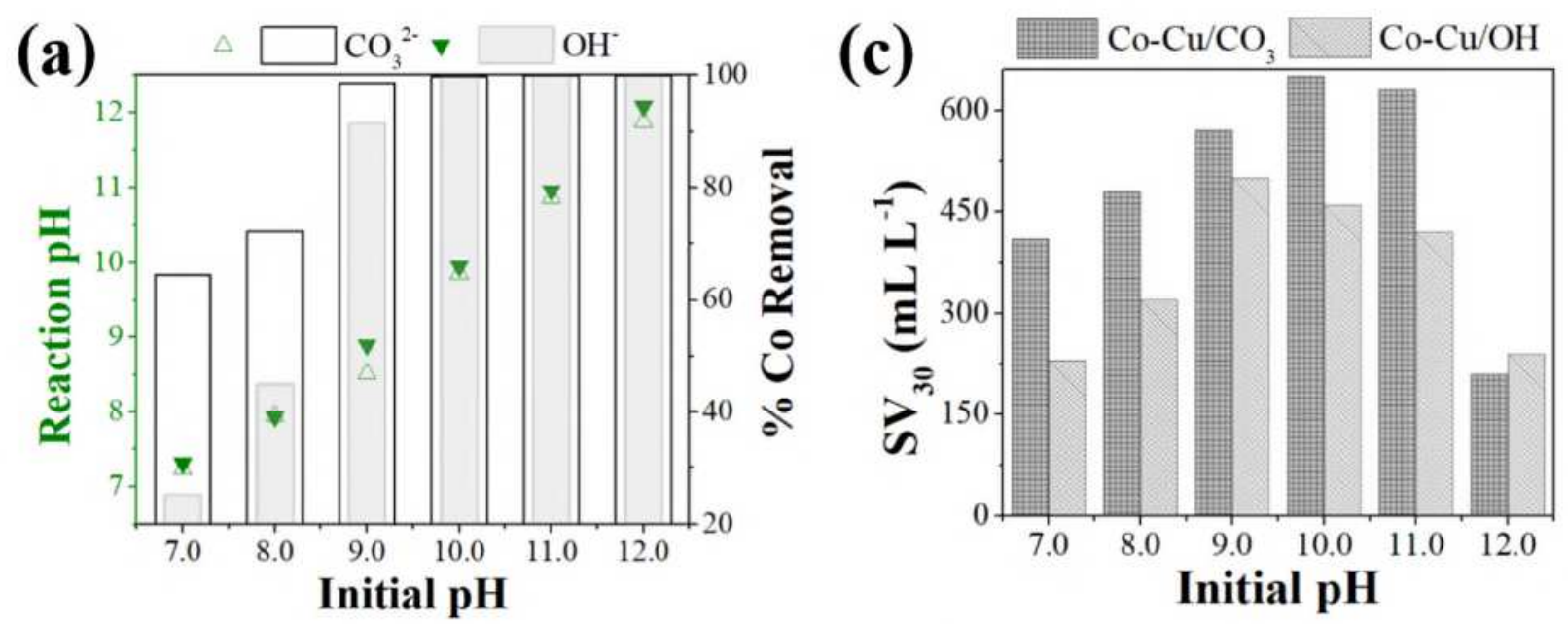

631
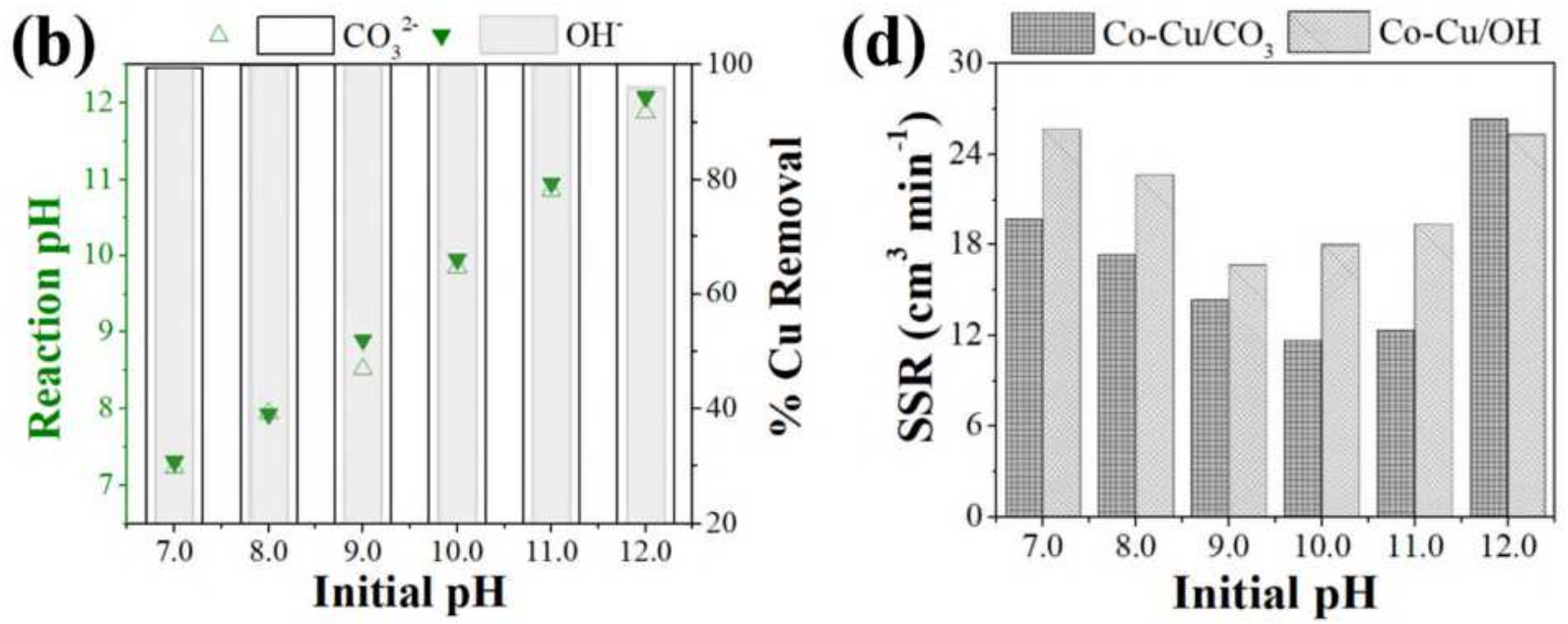

632

633

Fig. 5. Removal efficiency of (a) cobalt and (b) copper, (c) sludge volume at $30 \mathrm{~min}$ and (d) sludge settling rate in the co-contaminated system at different $\mathrm{pH}$ values using different precipitants.

635

636

637 

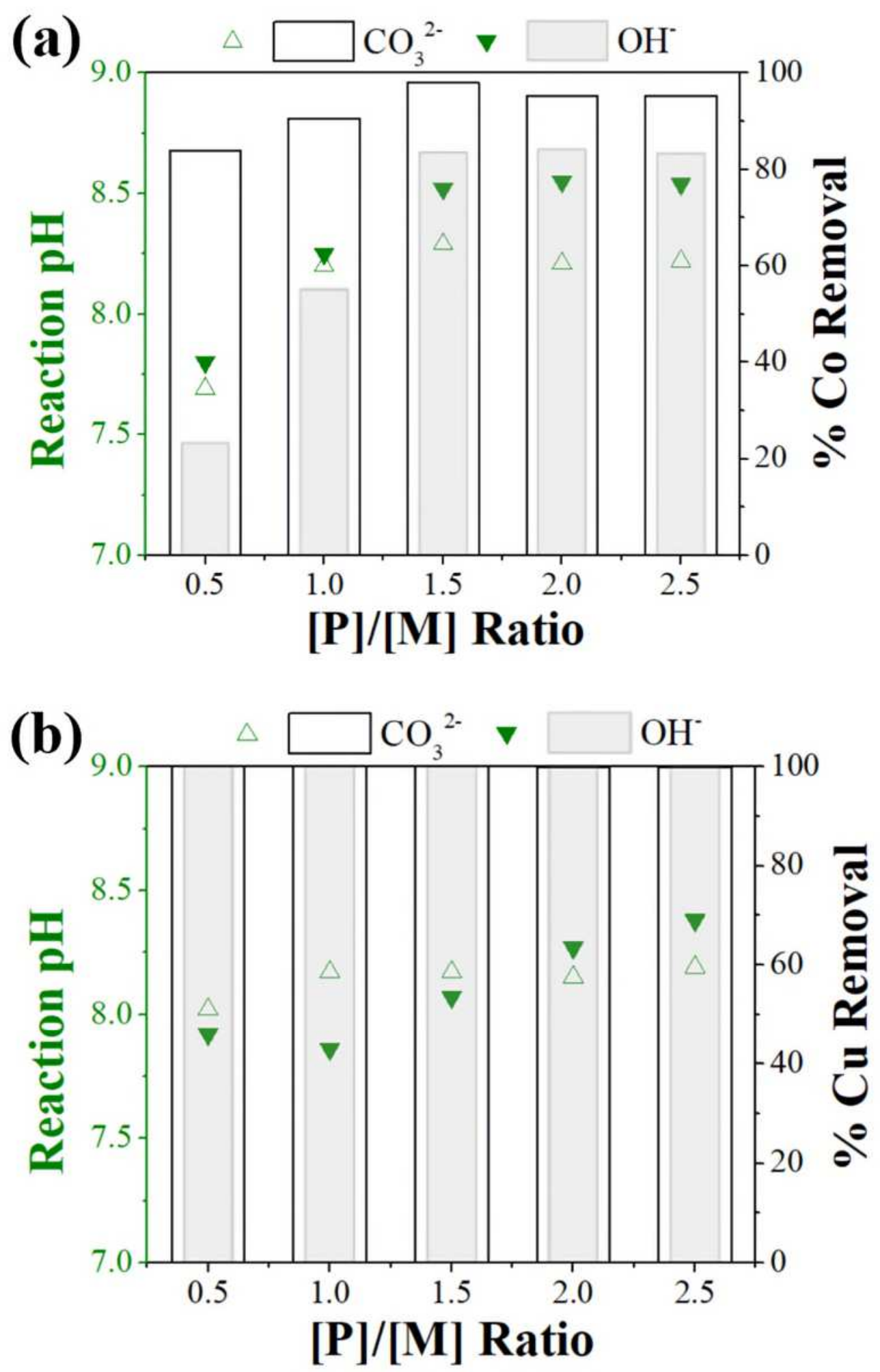

639 Fig. 6. Removal efficiency (a) cobalt and (b) copper at different $[\mathrm{P}] /[\mathrm{M}]$ values using different 640 precipitants (Conditions: $[\mathrm{Co}]_{\mathrm{o}}=[\mathrm{Cu}]_{\mathrm{o}}=12.6 \mathrm{mM} ; \mathrm{pH}=8.0 ;[\mathrm{P}] /[\mathrm{M}]=$ variable). 
(a)

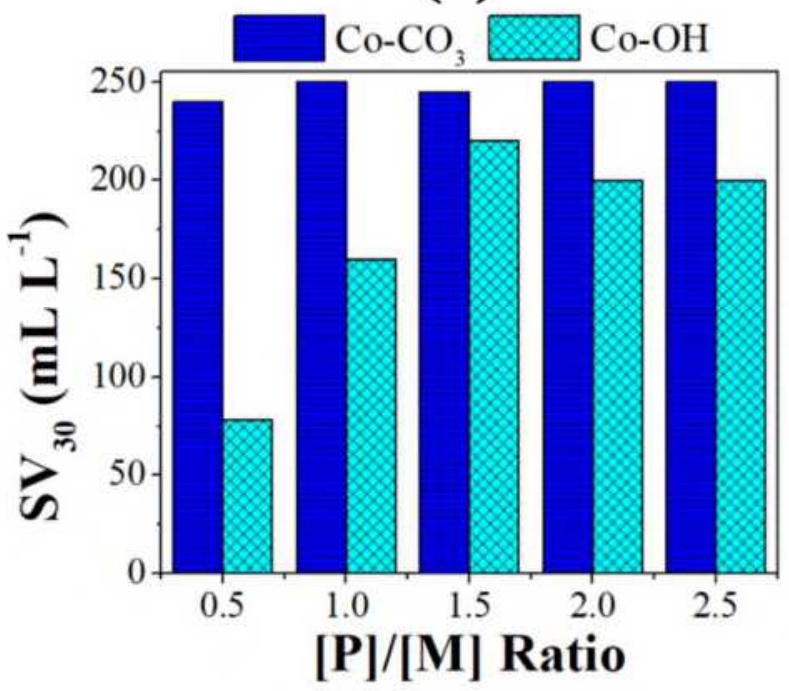

(b)

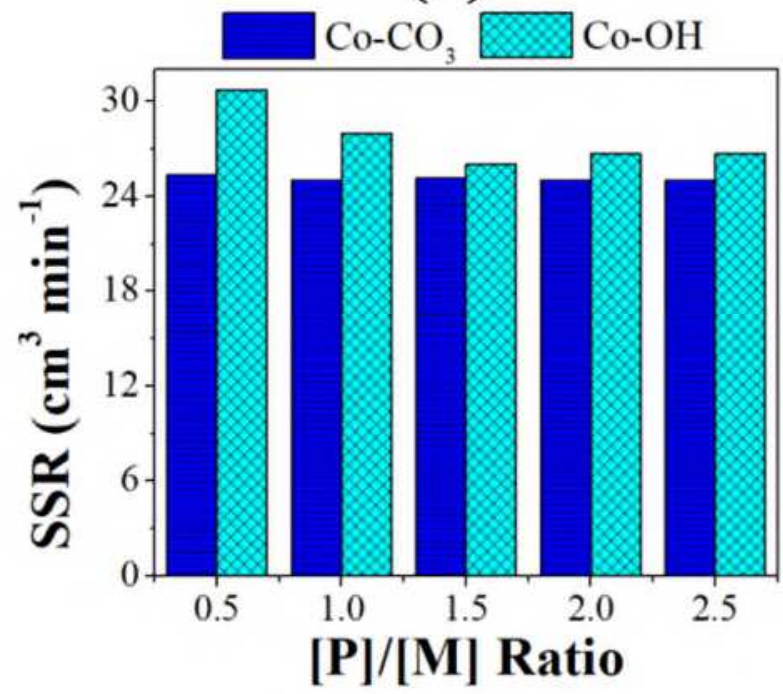

(c)

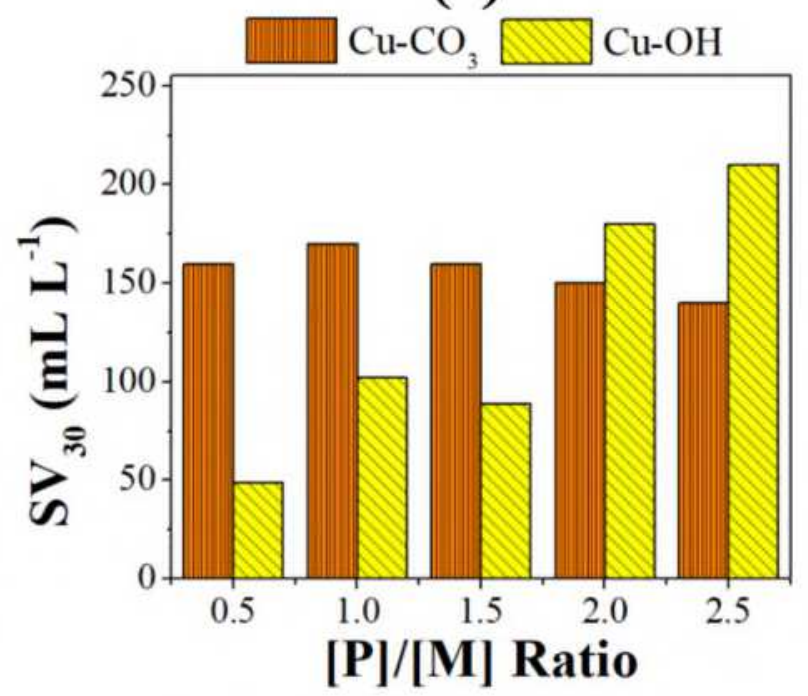

(d)

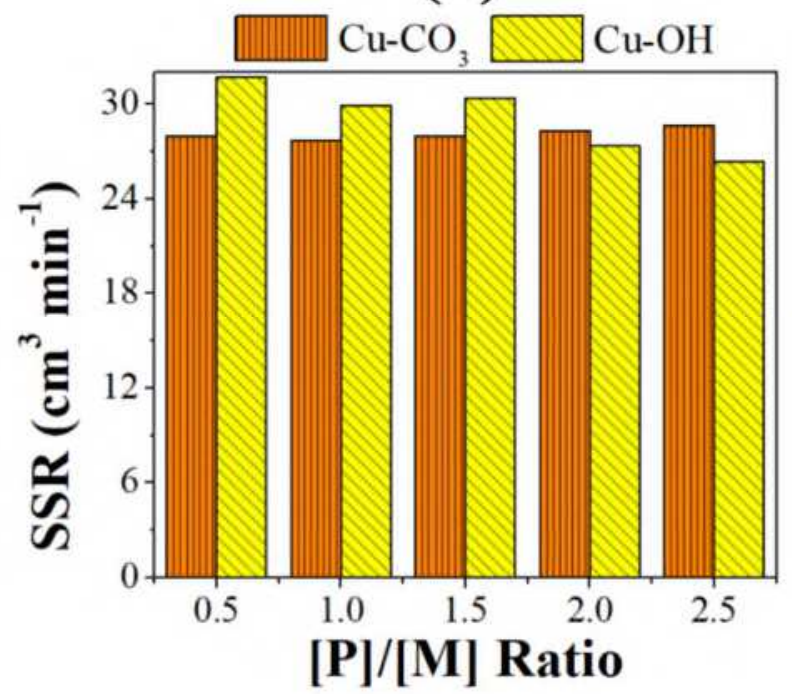

643 Fig. 7. Sludge volume at $30 \mathrm{~min}$ and sludge settling rate at different $[\mathrm{P}] /[\mathrm{M}]$ ratio for cobalt (a-b) 644 and copper (c-d) using different precipitants. 

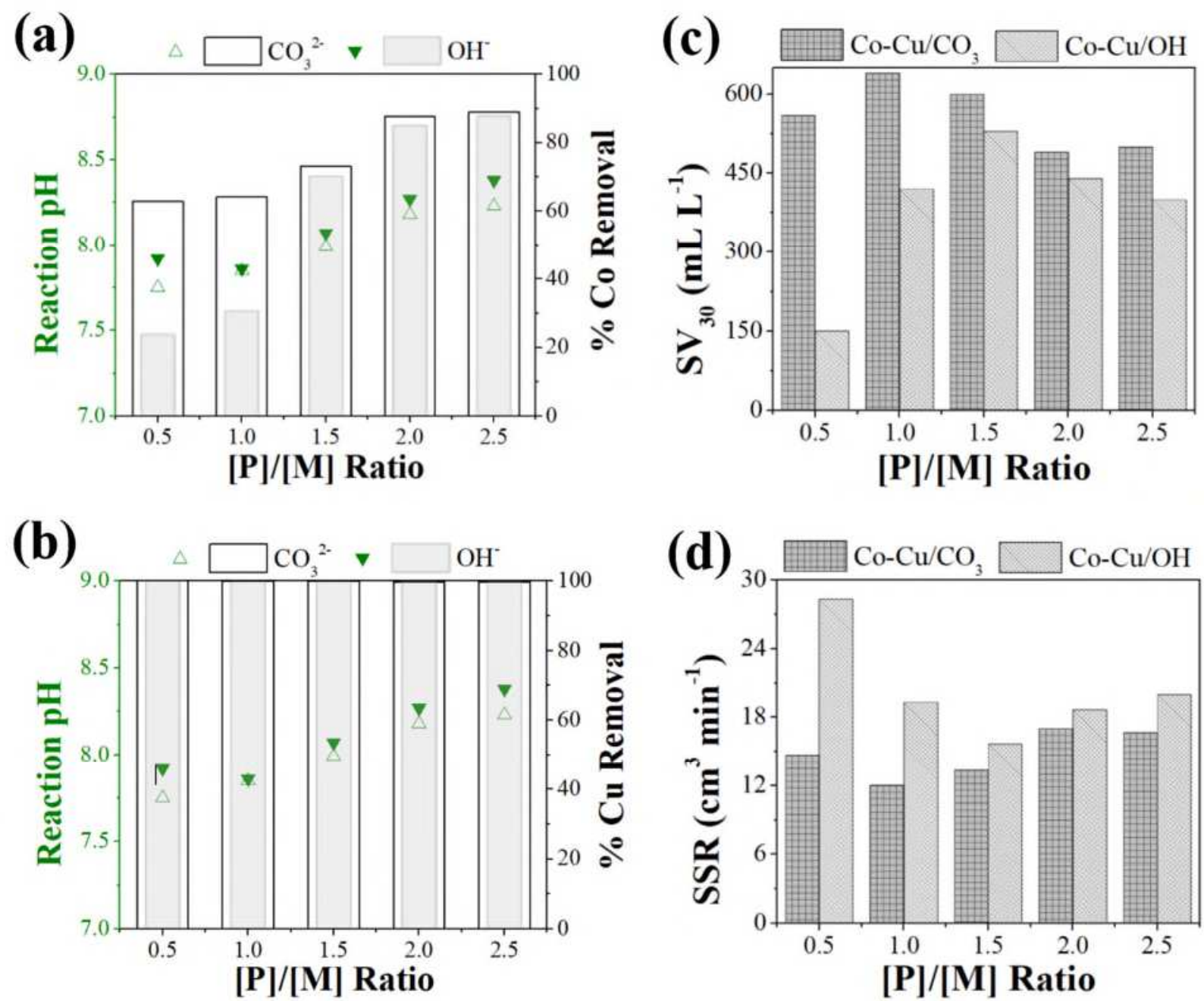

Fig. 8. Removal efficiency of (a) cobalt and (b) copper, (c) sludge volume at $30 \mathrm{~min}$ and $[\mathrm{P}] /[\mathrm{M}]$ ratio using different precipitants.

651

652

653

654

655

656

657

658 

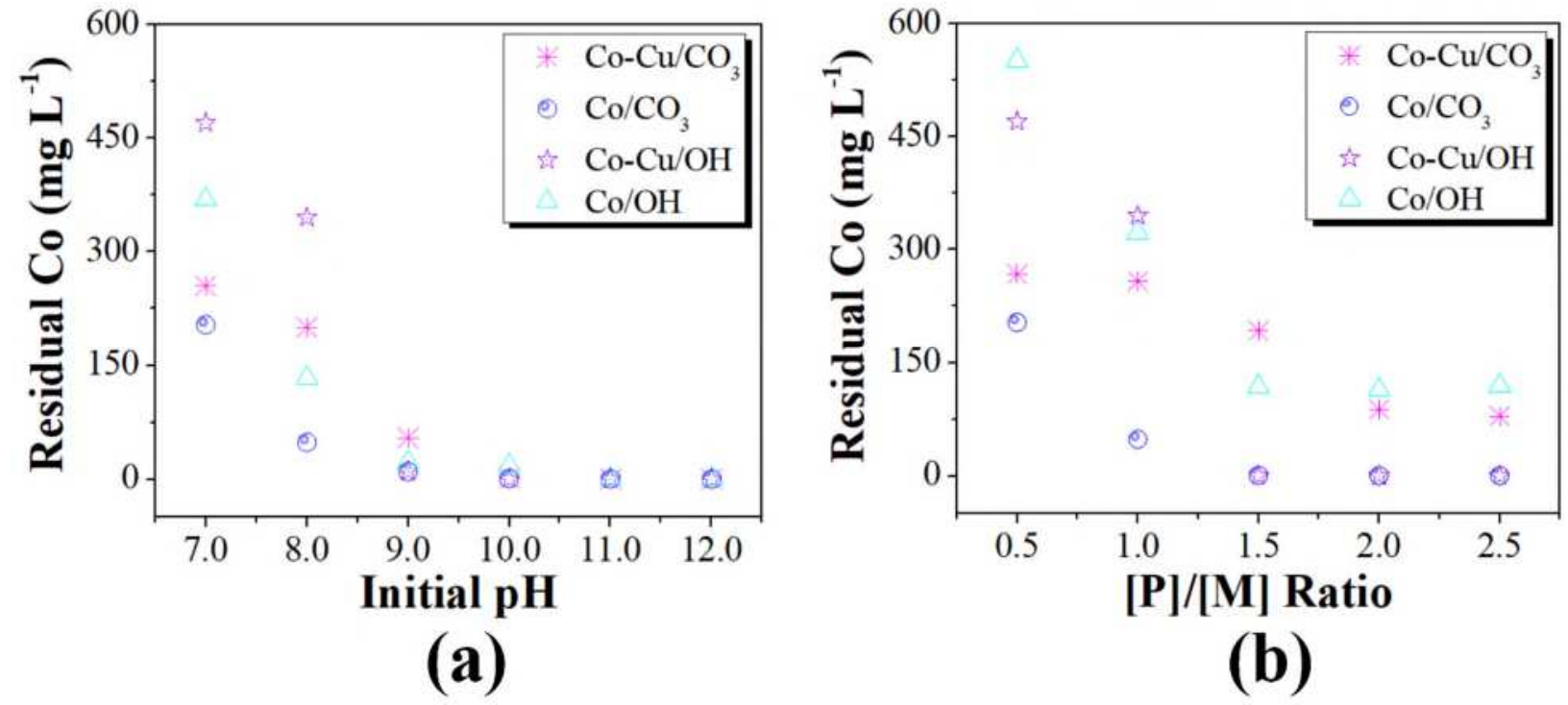

661

662

Fig. 9. Residual cobalt concentrations at different heavy metals systems at different (a) pH values and (b) precipitant-to-metal ratio via carbonate and hydroxide precipitation.

663

664

665

666
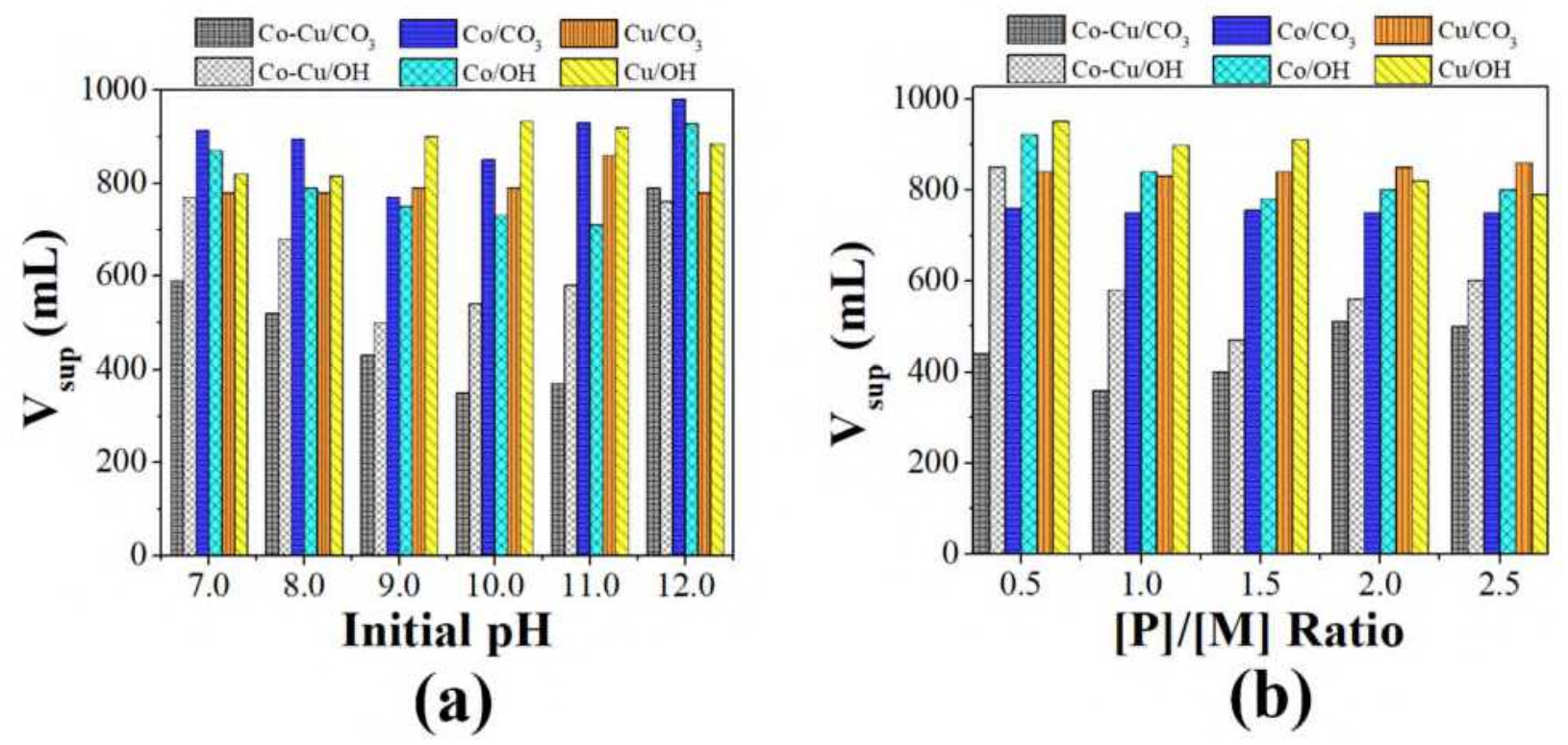

Fig. 10. Supernatant volume after 30 min under different heavy metals systems at different (a) $\mathrm{pH}$ values and (b) precipitant-to-metal ratio via carbonate and hydroxide precipitation. 